\title{
Leakage Management and Pipe System Efficiency. Its Influence in the Improvement of the Efficiency Indexes
}

\author{
Carlos Andrés Macías Ávila ${ }^{1}$ (D) Francisco-Javier Sánchez-Romero ${ }^{2} \mathbb{D}$, P. Amparo López-Jiménez ${ }^{1}$ (D) \\ and Modesto Pérez-Sánchez ${ }^{1, * \mathbb{D}}$ \\ 1 Hydraulic and Environmental Engineering Department, Universitat Politècnica de València, \\ 46022 Valencia, Spain; carmaav@posgrado.upv.es (C.A.M.Á.); palopez@upv.es (P.A.L.-J.) \\ 2 Rural and Agrifood Engineering Department, Universitat Politècnica de València, 46022 Valencia, Spain; \\ fcosanro@agf.upv.es \\ * Correspondence: mopesan1@upv.es
}

Citation: Ávila, C.A.M.;

Sánchez-Romero, F.-J.;

López-Jiménez, P.A.; Pérez-Sánchez,

M. Leakage Management and Pipe

System Efficiency. Its Influence in the Improvement of the Efficiency Indexes. Water 2021, 13, 1909. https://

doi.org/10.3390/w13141909

Academic Editor: Gordon Huang

Received: 2 June 2021

Accepted: 7 July 2021

Published: 9 July 2021

Publisher's Note: MDPI stays neutral with regard to jurisdictional claims in published maps and institutional affiliations.

Copyright: (c) 2021 by the authors. Licensee MDPI, Basel, Switzerland. This article is an open access article distributed under the terms and conditions of the Creative Commons Attribution (CC BY) license (https:// creativecommons.org/licenses/by/ $4.0 /)$

\begin{abstract}
Water is one of the most valuable resources for humans. Worldwide, leakage levels in water distribution systems oscillate between $10 \%$ and $55 \%$. This causes the need for constant repairs, economic losses, and risk to the health of users due to possible pathogenic intrusion. There are different methods for estimating the level of leakage in a network, depending on parameters such as service pressure, orifice size, age and pipe material. Sixty-two water distribution networks were analyzed to determine the leakage method used, the calibration method, and the percentage of existing leaks. Different efficiency indicators were proposed and evaluated using this database. Several cases of installation of pumps working as turbines (PATs) in water distribution networks were analyzed in which the use of these recovery systems caused a pressure drop, reducing the level of leaks and recovering energy.
\end{abstract}

Keywords: leakage; PATs; efficiency indexes; water networks; energy recovery

\section{Introduction}

Water is probably the world's most precious natural resource. It is sad then to think that so many people already live with less than their daily needs and that this situation is predicted to get even worse [1].

In a survey carried out by the International Water Services Association (IWSA), water losses vary between $8 \%$ and $24 \%$ in developed countries, $15-24 \%$ in newly industrialized countries, and $25-45 \%$ in developing countries [2]. Current statistical surveys indicated that $50 \%$ of the treated drinking water in city centers is lost and unaccounted for in big countries like Turkey [3]. According to other surveys [4], water leakages in a water distribution system may vary from $5 \%$ to $55 \%$ of the total supply and generally increase with pressure and it can therefore have an important effect on the operation of the system. When a network is simulated by a model considering the relationship between pressure and leakage flows, it can provide more realistic results compared to if no leakage is assumed [5].

Detecting and locating leaks in pipes has become an important aspect of water management systems. Since monitoring leakage in large-scale water distribution networks (WDNs) is a challenging task, the need to develop a reliable and robust leak detection and localization technique is essential for loss reduction in potable WDNs [6].

The literature describes different methods for detecting leaks in the water supply [6] classified leak detection methods as internal and external. The external detection methods are acoustics, fibre optics, gas injection, magnetic induction, ground penetration radar, among others. The internal methods are balancing methods, pressure/flow monitoring, signal processing approach, statistical analysis, model-based methods. Currently, the use of Transient Test-Based Techniques (TTBTs) is a good technique to improve the water management of the systems [7]. The merit of the TTBTs results from the simplicity and 
the limited cost of the equipment [8]. There is extensive literature which shows the development and progress of the current transitional theory, including transient flow models, models of unstable friction and turbulence and numerical simulation methods.

The contribution described in [9] presented a literature review of some major standpoints in hydraulic transient-based leak detection of pipe systems from 1992 to 2018. Reference [10] proposed a technique for leakage detection based on the well-known properties of transient pressure waves. A method for the analysis of inverse transients through a numerical model is proposed in [11].

This research focuses on model-based leakage detection methods. Reference [5] showed the formulation of a rupture prediction model that relates the rupture of a pipe with the exponent of its age, the optimal moment to replace a pipe, and the economic analysis with water losses for leaks.

Managing losses in water distribution systems efficiently is one of the key issues of water utilities. In particular, tools and methods for managing leakage are actively developed among components of losses [12]. There are many causes of such leakages, including natural process of wear, corrosion of the inner and outer surface of pipes, mechanical damage of pipes caused by excessive loads, assembling errors, seasonal temperature changes, movements of a subsoil, and material defects of pipes. The failure of pipelines is usually attributed to the ageing infrastructure and / or severe environmental conditions [13].

As water mains deteriorate both structurally and functionally, their breakage rates increase, network hydraulic capacity decreases and the water quality in the distribution system may decline [14]. A network with physical failures may be exposed, under certain operating conditions, to pathogen intrusions that affect the quality of water [15]. The leaky pipes increase pumping energy to guaranties the service levels. In addition, the energy wasted in leaks involves an environmental burden related to the many impacts associated with energy production and consumption, including greenhouse gas emissions, acid rain, and resource depletion [6].

The general objectives of pressure management for leakage minimization are threefold [16]: (i) reduce background leakage which refers to acoustically undetectable seeps at pipe joints and small cracks; (ii) decrease the rate of new leaks and breaks which occur on mains and service connections, due to diminished stress on the pipes; and (iii) minimize the flow rate from any leaks and breaks. To reduce leakage in the distribution network, it is necessary to apply models to know their efficiency volumetric. Different methods were found in the literature review discussed below.

Related to pressure management, one of the most used elements are pressure reduction valves (PRVs). A PRV consists of the main valve and a PRV controller which senses the output pressure and adjusts the opening of the main valve to maintain the outlet pressure at a given set-point, thereby reducing leakage and mitigating the stress on the downstream water distribution network. A research topic is how to understand and explain the instability phenomena in pressure control schemes for low flow rates (small valve openings) [17]. The results of a mathematical model representing the static and dynamic properties of a hydraulic controller and a PRV show good agreement with experimental data [18]. Optimization models through genetic algorithms are used to minimize leaks in water distribution sites through the most effective location and adjustment of control valves [19].

A hybrid multi-objective algorithm was established, which has as decisive variables the pipe diameter and the positions and settings of the valves. Analysis of the results shows that the new algorithm is more efficient than a multiobjective genetic algorithm widely adopted in the scientific literature [20]. The analysis of the tests demonstrates the versatility of PRVs as a powerful tool for pressure management, and also when the flow condition changes according to the users' demand pattern. Notwithstanding the crucial importance of PRVs, few experimental data are available in the literature [21]. The pressure control strategy through PRVs has been thoroughly researched as a management strategy. In contrast, little experimental data is available in the literature, regarding the transient 
behaviour of PRV in terms of its response to incoming pressure waves, as well as the time required to reach the pressure set point [22].

The use of pumps working as turbines (PATs) was proposed by [23] as an unconventional solution to reduce pressure and recovery energy. PATs are standard water pumps utilized as hydraulic turbines by reversing the flow direction across them. Electric power generation through PATs has a lower cost compared to hydraulic turbines. However, in the literature, the few available cost figures relative to PAT purchase price are discordant and often outdated, and such a lack of information is likely a severe barrier to a more widespread PAT implementation [24].

The application of PATs appears as an alternative and sustainable solution to either control network pressure as well as to produce energy [25]. Different pumps suitable to run in turbine mode for low capacity power generation in micro- hydropower plants as well as in water supply piping systems are discussed. The research work on PAT including criteria for selection of pump running as turbine, cavitation analysis, force analysis, loss distribution, various methods of performance enhancement, cost analysis of hydropower plant with conventional hydro turbine and PAT, applications of PAT in water supply pipelines, among others [26].

Performance data in pump and turbine mode were published in [27]. An energy evaluation is shown considering a test case of a water distribution network. Due to some problems such as limited resources and environmental pollution that they cause in recent years, researchers and engineers have focused on various types of renewable energies. Benefiting renewable resources improves air quality and prevents further greenhouse gas emissions [27]. Being the implementation of PATs a sustainable alternative for the reduction of leaks and energy production.

The objective of this research is to show the different methodologies to determine the leakage flow in distribution networks as well as the implications of leaks in volumetric performance, energy losses, and the costs associated with the loss of water and energy in forty-five case studies. The comparison between different case studies enables to show the range of the different key performance indicators (KPIs) applied to them.

\section{Leakages Evaluation and KPIs}

Different methods were used to estimate the leakages in the water systems. The most used are Torricelli theorem [16], MNF [28], Fixed and Variable Area Discharges (FAVAD) [6], N1 Power Law and leakages model [29], and Background and Bursts Estimates (BABE) [30].

Figure 1 shows the process and analysis carried out in this research. Forty-five different distribution networks were selected and analyzed for leaks. The leak calculation method implemented in the model was identified and relevant information was subsequently extracted from each case to calculate the efficiency indicators. The water distribution systems were different in terms of topology and pressure. However, to consider the general indicators and get the normalization of the different indicators, the research work with the value of average pressure to establish the correlation between indicator values. However, the different cases studies were analyzed in the different published studies considering the pressure value in the different leakage methods. 


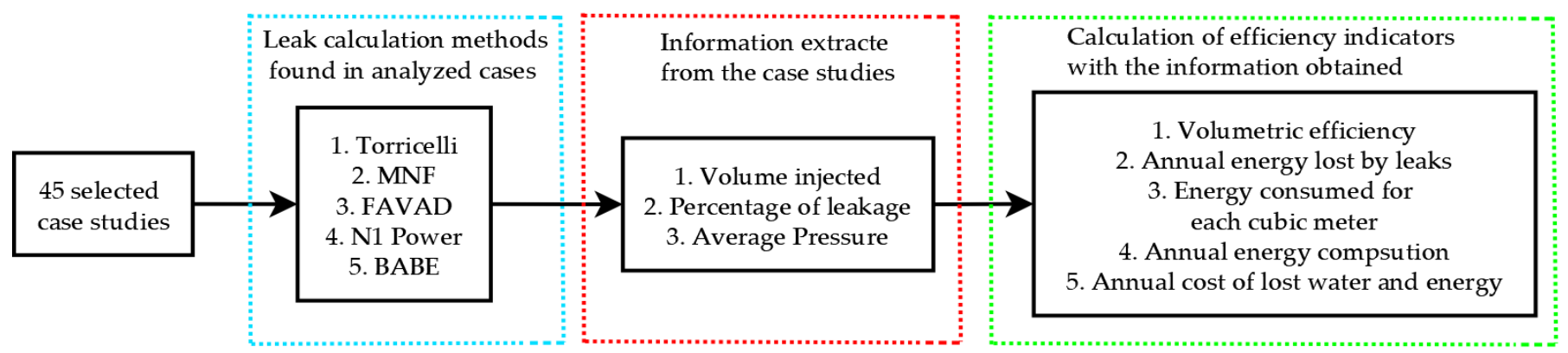

Figure 1. Analysis and calculations made to case studies.

\subsection{Torricelli Teorem}

The hydraulics of orifices is well understood, and a fair amount of research has been conducted on different orifice shapes and conditions. In Torricelli's equation, the velocity through an orifice is expressed as [31]:

$$
v=\sqrt{2 g h}
$$

where $v$ is the theoretical velocity $\left(\mathrm{ms}^{-1}\right) ; g$ is the acceleration due to gravity $\left(\mathrm{ms}^{-2}\right)$ and $h$ is the pressure head ( $m$ w.c.).

The starting point is that water leakages in WDN are directly related to pressure as well as to the age and material of WDN elements (joints, valves, pipes, etc.). Many numerical models were developed starting from experimental observations and assuming the validity of the Torricelli law in the following form, which is valid for a single leak orifice [30].

One of the major factors that influence leakage rate is the pressure in the distribution system. A conventional physical model that relates the pressure and the leakage rate is the well-known Torricelli orifice equation, described as [32]:

$$
Q_{\text {leak }}=C_{d} A \sqrt{2 g h}
$$

where $Q_{\text {leak }}$ represents the leakage flow rate, $C_{d}$ is the leakage discharge coefficient, $h$ denotes the pressure head, and $A$ the area of the leak opening in $m^{2}$. However, from several studies on real WDNs, it has been shown that the Torricelli law does not provide a satisfactory model for the relationship between leakages with pressure within a WDN [30].

\subsection{Minimum Night Flow (MNF) Analysis}

Minimum Night Flow (MNF) analysis is the most common method for leakage assessment at the scale of the DMA. The MNF is the lowest inflow in the DMA over $24 \mathrm{~h}$ along the day, which occurs depending on consumption patterns but reportedly, between 02:00 and 04:00 AM when most of the customers are probably inactive and the flow at this time is predominantly leakage [33]:

$$
L_{D M A}=Q_{M N F}-Q_{L N C}
$$

where $L_{D M A}$ is the leakage rate in the $D M A\left(\mathrm{~m}^{3} \mathrm{~h}^{-1}\right)$ at the time hour of $M N F, Q_{M N F}$ is the minimum flow rate $(M N F)$ and $Q_{L N C}$ is the legitimate nighttime consumption in the $D M A$ at the $M N F$ time.

The leakage in the MNF time cannot be generalized for all the hours of the day because of the pressure leakage relationship, where higher pressure at night leads to higher night leakage and lower pressures during the day lower the day leakage. For this reason, the MNF leakage should be modelled according to the leakage-pressure relationship [28]. Lambert [34] in his research shows three basic steps that must be performed to determine the MNF. 
Once the leakage flow has been obtained in the hour of the night minimum, its value can be extrapolated to the rest of the hours using a multiplying factor known as the hourday factor (HDF). The HDF represents the change throughout the day of the leakage flow and it is proportional to the pressure variation in the network for the pressure of the hour of minimum night flow. This pressure variation is calculated in the Average Zone Pressure $(A Z P)$, which is assumed to be the most representative point of pressure in the network, therefore [35]:

$$
Q_{\text {leak }(t)}=Q_{L}\left(t_{M N F}\right) \cdot\left[\frac{P_{A Z P(t)}}{P_{A Z P}\left(t_{M N F}\right)}\right]^{\alpha}
$$

where $Q_{\text {leak }(t)}$ is the leakage flow at a different time from that considered for the night minimum, $\left(t_{M N F}\right)$ is the time at which the night minimum flow is measured, $P_{A Z P(t)}$ is the pressure in the $A Z P$ (selected as point average of the pressures in the network), $P_{A Z P}\left(t_{M N F}\right)$ is the pressure in the $A Z P$ at the hour $\left(t_{M N F}\right)$ and finally, $\alpha$ is the exponent of the emitter. This equation is based on the FAVAD theory. Stenberg [36] has found that night leakage flow rates should then be multiplied by $20 \mathrm{~h}$. This assumption does not consider that pressure is not constant over a period.

\subsection{FAVAD Concept}

A variety of different concepts have been proposed to explain the diversity of pressure: leakage rate relationships including the widely used fixed and variable area discharge (FAVAD) model. This model offers a means to demonstrate the sensitivity to the pressure of different leaks and to quantify the change of the area of elastically deforming leaks subject to hydraulic pressure loading [16].

The FAVAD concept, as realistic modelling of leakage and intrusion, flows through leak openings in pipes in water supply systems, allows for variations in the area of leaks resulting from changes in pressure [34]. The FAVAD concept as the principle of conservation of energy provides a logical hydraulic basis to explain, analyze and predict diverse relationships between Average Zone Pressure (AZP) and leak flow rates [37].

Emitters are devices associated with junctions that model the flow through a nozzle or orifice that discharges to the atmosphere [38]. The technique for a more consistent description of demands is to allocate part of the total metered inflow to the leakage component, and account for this as a pressure-dependent demand [39].

When the leakage flow at each pipe is known, this value can be assigned to each node according to Equation (5) [40]:

$$
q l_{i}=C_{i} \cdot P_{i}^{\beta}
$$

where $q l_{i}$ is the leakage flow at node $1 \mathrm{~s}^{-1}, \beta$ is the emitter exponent which takes into account the pipe material and the shape of the orifice, and $P_{i}$ is the pressure at node $i$. [41] defined the leakage exponent as $\alpha$, which is sometimes called $N_{1}$. The coefficient $C_{i}$ was determined by equation:

$$
C_{i}=\alpha \cdot 0.5 \cdot \sum_{j=1}^{K_{j i}} L_{j i}
$$

$\alpha$ is a coefficient $\left(1 \mathrm{~s}^{-1} \mathrm{~m}^{-1-\beta}\right), j$ is an index related to pipe, $K_{j i}$ is the number of pipes connected to node $i$ and $L_{j i}$ is the length of pipe $j$ connected to node $i(\mathrm{~m})$. The leakage volume was obtained by applying the equation:

$$
V l=\frac{1}{1000} \cdot \sum_{h=1}^{24} Q l_{h} \Delta h
$$

where the term $1 / 1000$ is used to convert units from $1 \mathrm{~s}^{-1}$ to $\mathrm{m}^{3} \mathrm{~s}^{-1}, \mathrm{Ql} h$ is the total leakage flow at time $h$ and $\Delta h(s)$ is the time in which $Q l_{h}\left(1 \mathrm{~s}^{-1}\right)$ is applied. 
$\alpha$ and $\beta$ variables are two leakage model parameters, representing the influence of some factors on the relationship leakage/pressure. Parameter $\beta$ can represent the pipe deterioration over time, thus it depends on both pipe characteristics (pipe age, diameter, and material) and various external factors (mainly the average pressure, but also other environmental conditions, traffic loading, external stress, and corrosion, etc.). In contrast, $\alpha$ is a function of pipe characteristics only (material and elasticity) $[16,30]$.

In general, $\beta$ is more closely related to the number of leaks (or leakage area) per unit of pipe length while $\alpha$ is more strongly related to the type of leakage (therefore to the hydraulics of leakage) as governed by the pipe material. For this reason, changes in $\beta$ need to be determined for the specific system, i.e., by model calibration, while most experimental studies have focused mainly on leakage parameter $\alpha[4,30]$. Table 1 shows the range of $\alpha$ and $\beta$ coefficients for different pipe materials.

Table 1. Coefficients for different materials.

\begin{tabular}{ccc}
\hline Material & $\alpha$ & $\beta$ \\
\hline Cement & $10^{-7} \leq \alpha \leq 10^{-5}$ & $0.75 \leq \beta \leq 1.10$ \\
\hline Steel & $10^{-6} \leq \alpha \leq 10^{-4}$ & $1 \leq \beta \leq 1.3$ \\
\hline PVC & $10^{-5} \leq \alpha \leq 10^{-4}$ & $1.1 \leq \beta \leq 1.5$ \\
\hline
\end{tabular}

The value of the leakage parameter, $\alpha$, can be described using the fixed and variable area discharge (FAVAD) approach. The range of exponents observed reflects substantial differences in the impact of pressure on the rate of leakage. For example, when the pressure halved in a pipe it caused a decrease of the flow rate of $29 \%, 50 \%$ and $82 \%$ respectively, when the exponents were 0.5, 1.0 and 2.5 [41]. Reference [42] showed the coefficient is a function of the length of the pipe and the type of material in the network. Table 2 shows the leakage emitter exponent used in different study cases. It is observed that the most used emitter exponent in the analyzed case studies is 0.5 , however, in some cases, they use different coefficients to observe the sensitivity of the parameter to the model.

Table 2. Case study emitter exponent.

\begin{tabular}{cccr}
\hline Reference & ID & Emitter Exponent & Material \\
\hline$[29,43-48]$ & $7,9,12,13,27,33$ & 0.5 & PVC, HDPE, steel, asbestos cement and cast iron \\
\hline$[49]$ & - & 0.61 & PVC, asbestos cement, galvanized steel \\
\hline$[50]$ & 8 & $0.5-1$ & PVC, Polyethylene (PE), iron, steel. \\
\hline$[51]$ & 1 & $0.91-1.13-1.41$ & PVC, metal, ambient. \\
\hline$[52,53]$ & 2,10 & 1.1 & PVC, iron. \\
\hline$[54]$ & 5 & $0.5-1.18$ & - \\
\hline$[55]$ & 3 & $1.1-1.18$ & Ductile iron, Steel, High-Density Polyethylene \\
(HDPE)
\end{tabular}


The research described in [63] confirmed that the leak exponents can be significantly higher than the theoretical value of 0.5 . While leakage exponents for round holes were near 0.5 , the values for corrosion holes varied between 0.67 and 2.30, for longitudinal cracks between 0.79 and 1.85 , and circumferential cracks between 0.41 and 0.52 . A variety of different concepts have been proposed to explain the diversity of pressure: leakage rate relationships including the widely used fixed and variable area discharge (FAVAD) model [64].

\subsection{FAVAD and the N1 Power Law}

The $N_{1}$ Power Law an approximate version of the FAVAD concept-has been increasingly used internationally since 1994 for practical assessment of pressure-dependent leakage in water distribution systems. The estimation of system leakage and average zone pressure head (AZP) before and after pressure management can be used to estimate the leakage coefficient $C$ and leakage exponent $N_{1}$ [65]. When modelling the pressure-leakage rate relationship in individual water distribution systems, a more general form expression was proposed instead of the orifice equation [37]:

$$
Q_{\text {leak }}=C h_{A Z P}^{N_{1}}
$$

where $Q_{\text {leak }}$ is the leakage flow rate and $h A Z P$ the $A Z P$. Equation (8) is also called the $N_{1}$ power-law or the $N_{1}$ equation. The $N_{1}$ Power Law approximation simplifies FAVAD by assuming that the leak flow rate varies with average pressure $N_{1}$, where $N_{1}$ lies between 0.5 (less sensitive) and 1.5 (more sensitive). FAVAD and $N_{1}$ are both widely used internationally in distribution systems and laboratory tests [34].

Different investigations $[63,66,67]$ experiment with the materials of the pipes to calibrate the parameters of $C$ and $N_{1}$, according to the orifice in the pipe, it is transverse, longitudinal or circular (Table 3 ).

Table 3. Summary of leakage exponents $N_{1}$.

\begin{tabular}{cccc}
\hline Failure Type & uPVC & Asbestos Cement & Mild Steel \\
\hline Round hole & 0.52 & - & 0.52 \\
\hline Longitudinal crack & $1.38-1.85$ & $0.79-1.04$ & - \\
\hline Circumferential crack & $0.41-0.53$ & - & - \\
\hline Corrosion cluster & - & - & $0.67-2.30$ \\
\hline
\end{tabular}

The median used is 1.15 depending on the mixture of leaks and the dominant type of leaks (fixed area leaks: $N_{1}=0.5$; longitudinal split which opens in one dimension: $N_{1}=1.5$; linear-radial opening: $N_{1}=2.0-2.5$ ). Typically found in the literature an exponent value of 0.5 [16]. Ref. [15] presented a methodology for evaluating water losses where a sensitivity analysis of the coefficients is carried out to determine the influence of various leakage exponents on the results of the study.

\subsection{Background Leakage and Emitter Coefficient (BABE)}

It is assumed that leakage continuously increases with pressure and can be expressed as the sum of the background leakage and the burst leakage. So, the pressure-leakage relationship for a pipe $k$ can be stated as follows:

$$
q_{k}^{\text {leak }}\left(P_{k}\right)= \begin{cases}\beta_{k} l_{k}\left(P_{k}\right)^{\alpha_{k}}+C_{k}\left(P_{k}\right)^{\delta_{k}} & P_{k}>0 \\ 0 & P_{k} \leq 0\end{cases}
$$

where $q_{k}^{\text {leak }}$ is the total leakage along pipe $k(m) ; l k$ is the length of pipe $k(m) ; \alpha_{k}$ and $\beta$ are parameters of the background leakage model; $C_{k}$ and $\delta_{k}$ are parameters of the bursts leakage model; and $P_{k}$ is the average pressure $(m)$ in pipe $k$ computed as the mean of the 
pressure values of its end nodes. The leakage model assumes a uniform distribution along the pipe [4], which is the most common experimental relationship between leakage and pressure [5]. Several studies model leaks along the pipe $[16,60,68]$. For each pipe, the total leakage is assigned to its end nodes, half to each node. So, the nodal leakage flow $q_{i}^{\text {leak }}$ for a node $i$ can be computed as follows:

$$
q_{i}^{\text {leak }}=\frac{1}{2} \sum_{k} q_{k}^{\text {leak }}
$$

\subsection{Summary of Leak Calculation Methodologies}

As mentioned above, there are different methodologies to calculate water leaks in distribution networks. These methods are used in designs to know the leakage percentage of a network. Table 4 shows the calculation equations, parameter calibration methods, advantages and disadvantages of the leakage methodologies described in this research. 
Table 4. Methodologies for calculating leaks.

\begin{tabular}{|c|c|c|c|c|c|}
\hline Technique & Reference & Equation & Calib. & Advantages & Disadvantages \\
\hline Torricelli & {$[16,69-73]$} & $Q_{l e a k}=C_{d} A \sqrt{2 g h}$ & & $\begin{array}{l}\text { - } \quad \text { Pressure dependent } \\
\text { - } \quad \text { The scale is system-wide }\end{array}$ & $\begin{array}{l}\text { - Only applicable for rigid pipe orifices } \\
\text { Does not consider the flexibility of the } \\
\text { pipes } \\
\text { It does not provide a satisfactory } \\
\text { model of the relationship between } \\
\text { leakage and pressure. }\end{array}$ \\
\hline MNF & $\begin{array}{c}{[28,29,35,44,47,70} \\
74-76]\end{array}$ & $\begin{array}{c}L_{D M A}=Q_{M N F}-Q_{L N C} \\
Q=Q\left(t_{M N F}\right) \cdot\left[\frac{P_{A Z P(t)}}{P_{A Z P}\left(t_{M N F}\right)}\right]^{\alpha}\end{array}$ & & $\begin{array}{l}\text { - No need lots of network data } \\
\text { - No need for a mathematical model }\end{array}$ & $\begin{array}{l}\text { - Need to data loggers and mechanical } \\
\text { flow meter } \\
\text { - } \quad \text { Needs measurements } \\
\text { - Intensive fieldwork, zoning }\end{array}$ \\
\hline $\begin{array}{c}\text { FAVAD } \\
\text { (Fixed and Variable } \\
\text { Area Discharges) }\end{array}$ & $\begin{array}{c}{[6,16,29-} \\
31,34,36,37,42,45 \\
49,50,53,55,59,62 \\
64,65,69,71,73,77- \\
84]\end{array}$ & $\begin{array}{l}\text { The equation can be written } \\
\text { in different ways: } \\
\begin{array}{c}Q_{i, l}(t)=K_{i}\left[P_{i}(t)\right]^{\alpha} \\
L=c P^{\gamma} \\
q l_{i}=c_{i} \cdot P_{i}^{\beta} \\
Q_{\text {leak }}=\beta P^{\alpha}\end{array}\end{array}$ & $K_{i}, C, \beta[59,66,78]$ & $\begin{array}{l}\text { - Consider that the area of the orifice } \\
\text { varies with pressure } \\
\text { - } \quad \text { Pressure dependent } \\
\text { burstyse field data and volumes of } \\
\text { background leaks } \\
\text { - The scale is to District Metered } \\
\text { Area (DMA) }\end{array}$ & $\begin{array}{l}\text { - } \quad \text { Many assumptions } \\
\text { - Further calibrations are useful }\end{array}$ \\
\hline The N1 Power Law & $\begin{array}{c}{[29,31,34,37,43,63} \\
\quad 65-67,76,84]\end{array}$ & $Q=C_{d} h_{A Z P}^{N_{1}}$ & $N_{1}[59,66]$ & $\begin{array}{l}\text { - } \quad \text { Pressure dependent } \\
\text { - } \quad \text { The scale is system-wide }\end{array}$ & $\begin{array}{l}\text { - It is an empirical equation and } \\
\text { therefore not founded on fundamental } \\
\text { principles of fluid mechanics. } \\
\text { The values of } \mathrm{C} \text { and N1 are not } \\
\text { constant for a given system but } \\
\text { depending on the pressures at which } \\
\text { they are being estimated. } \\
\text { The equation is dimensionally } \\
\text { awkward since the units of } \mathrm{C} \text { include } \\
\text { the variable N1. }\end{array}$ \\
\hline $\begin{array}{c}\text { Background } \\
\text { leakages model }\end{array}$ & $\begin{array}{l}{[5,16,37,43,60,68} \\
\quad 76,83-91]\end{array}$ & $Q=\beta_{k} l_{k}\left(P_{k}\right)^{\alpha_{k}}+C_{k}\left(P_{k}\right)^{0.5}$ & $\beta$ and $\alpha[4], \beta[85,89]$ & $\begin{array}{l}\text { - } \quad \text { Consider leaks along the pipe } \\
\text { - } \quad \text { Pressure dependent } \\
\text { - } \quad \text { The scale is system-wide }\end{array}$ & - $\quad$ Further calibrations are useful \\
\hline
\end{tabular}




\subsection{Leakages Modelling and Calibration}

In a distribution network under MNF conditions, using leakage and pressure data, the leakage exponent of the system was determined by the following expression. From the two data sets, system leakage exponent $N_{1}$ was calculated using the equation below [76]:

$$
N_{1}=\frac{\log \left(\frac{Q_{1}}{Q_{2}}\right)}{\log \left(\frac{A Z P_{1}}{A Z P_{2}}\right)}
$$

where $Q_{1}$ and $Q_{2}$ are system leakages and $A Z N P_{1}$ and $A Z N P_{2}$ are average zone night pressures before and after pressure reduction, respectively. Van Zyl, Lambert, and Collins [77] suggested a modified version of the orifice equation where fixed orifice area and flexible orifice area are considered as shown in Equation (12):

$$
Q_{\text {leak }}=\operatorname{sgn}(h) C_{d} A \sqrt{2 g}\left(A_{0}|h|^{0.5}+m|h|^{1.5}\right)
$$

where Qleak is leakage flow, $\operatorname{sgn}(h)$ is the sign function, $C_{d}$ is the discharge coefficient, $h$ is the pressure head, $g$ is the acceleration of gravity and $A_{0}$ is the initial area of the orifice.

Calibration methods can leverage steady-state hydraulic models and optimization tool technology, such as Genetic Algorithms (GAs) to improve the detection of a leak [61,92]. Reference [62] proposed a methodology for the estimation of $C$ and $\gamma$, based on the solution of an inverse modelling problem where demand and leakage pattern are assumed as unknowns, is solved using GAs. Reference [4] proposed a genetic algorithm using Epanet to calibrate the alpha and beta coefficients in a network and shows the variation of the coefficients in the case of new and old pipes. Reference [69] showed a table of calibrated coefficients, which were determined through experimental tests on PVC and Steel materials from 1" to 3" with holes from 1.5 to $10 \mathrm{~mm}$. References [12,93] proposed a method of estimating area leakages in virtual areas of a water network to prioritize leak surveys for the areas.

To calibrate both emitter $C$ and exponent $N_{1}$ coefficients, the leakage flow rate was calculated as the difference between the upstream and downstream measured flow rates, this methodology is described in [66]. This research used a CFD model with experimental results to different geometric configurations of the orifice, to assess the dependence of the orifice geometry and orientation on the calibration of leakage law parameters.

Reference [92] showed a GA. This is used to solve optimization problems of searching for calibration parameters values while minimizing the differences between observations and model predictions. A Matlab optimization code was developed for model calibration and was linked to the Epanet toolkit. The optimization process uses a nondominated sorting genetic algorithm II (NSGA II) [94]. A multi-objective procedure based on non-dominated sorting GAs has been developed to calibrate a water supply system characterized by elevated pressure and a high amount of background leakages [89].

Reference [85] used a method of optimization in the network through a differential evolution algorithm (DE). It is a simple power and population-based stochastic optimization algorithm that outperforms many meta-heuristic algorithms on numerical single-objective optimization problems.

Reference [95] proposed a method of optimization using is the BOBYQA algorithm, this model is an iterative algorithm for finding a minimum of a function. Table 5 shows a summarize of the used algorithms. 
Table 5. Summary of optimization algorithms.

\begin{tabular}{|c|c|c|c|c|}
\hline Reference & Algorithm & Parameters & Objective Function & Error \\
\hline $\begin{array}{c}{[4,39,52,54,61,62,81,83} \\
89,92,96-98]\end{array}$ & Genetic algorithm. & $\begin{array}{l}\text { Operation conditions, } \\
\text { flows, demands, } \\
\text { pressures, total leakage. }\end{array}$ & $\begin{array}{l}\text { Minimize network } \\
\text { pressure and producing } \\
\text { a new generation of } \\
\text { solutions } \alpha \text { and } \beta \text {. }\end{array}$ & $\begin{array}{c}0.5 \text { to } 23 \% \text {, with an } \\
\text { average value of } 11 \% \text {. }\end{array}$ \\
\hline$[6,29,91]$ & $\begin{array}{l}\text { Algorithm for detecting } \\
\text { and estimating } \\
\text { background leakage. }\end{array}$ & $\begin{array}{l}\text { Operation conditions } \\
\text { flow, pressure and fluid } \\
\text { temperature. }\end{array}$ & $\begin{array}{l}\text { Detect critical causes } \\
\text { and their location for } \\
\text { possible pressure } \\
\text { control. }\end{array}$ & - \\
\hline [88] & $\begin{array}{l}\text { Pseudogenetic } \\
\text { algorithm. }\end{array}$ & Basic network & $\begin{array}{l}\text { Operational costs, } \\
\text { capital costs (pipe and } \\
\text { pump replacement, } \\
\text { tank expansion, and } \\
\text { PRVs), and constraints. }\end{array}$ & - \\
\hline [76] & $\begin{array}{l}\text { Global Gradient } \\
\text { Algorithm. }\end{array}$ & Flow, pressure. & Reduce excess pressure. & - \\
\hline [1] & Neural networks. & Flow, pressure. & $\begin{array}{c}\text { Detection of water } \\
\text { leaks. }\end{array}$ & \\
\hline [99] & $\begin{array}{c}\text { Differential evolution } \\
\text { with temporal analysis. }\end{array}$ & $\begin{array}{l}\text { Water distribution } \\
\text { network. }\end{array}$ & $\begin{array}{c}\text { Estimation and location } \\
\text { to leakage. }\end{array}$ & $\begin{array}{l}\text { Root mean squared } \\
\text { error: } 0.05\end{array}$ \\
\hline [85] & Differential evolution. & $\begin{array}{l}\text { Flow, pressure, } \\
\text { network data. }\end{array}$ & Estimation of leakage. & - \\
\hline [100] & $\begin{array}{c}\text { Algorithm with } \\
\text { convergence analysis. }\end{array}$ & $\begin{array}{l}\text { Operation conditions, } \\
\text { flows, demands, } \\
\text { pressures. }\end{array}$ & Estimation to leakage & - \\
\hline [54] & $\begin{array}{l}\text { Sequential Quadratic } \\
\text { programming. }\end{array}$ & $\begin{array}{l}\text { Water distribution } \\
\text { network. }\end{array}$ & Leakage minimization & - \\
\hline
\end{tabular}

\subsection{Leakages Key Performance Indicators (LKPIs)}

Performance indicators are a powerful management tool, they can provide measures of how many resources are being used relative to those available, they can be used to assess the extent to which management objectives are being met, and even to assess the overall impact of strategies management [101]. Some proposed key performance indicators leakages are pressure-dependent demand, volumetric efficiency, performance indicators for water supply services:

Pressure-dependent demand concept; Two types of pressure-dependent demands are considered: consumptions and leakage (background and bursts). For pressure-dependent consumption, it is assumed that the available demand $\left(q_{i}^{a v l}\right)$ is computed with the pressuredemand relationship [86,91]:

$$
q_{i}^{a v l}\left(P_{i}\right)=q_{i}^{r e q} \cdot\left\{\begin{array}{cc}
1 & P_{i} \geq P_{i}^{r e f} \\
\left(\frac{P_{i}-P_{i}^{\text {min }}}{P_{i}^{r e f}-P_{i}^{\text {min }}}\right)^{\alpha} & P_{i}^{\text {min }} P_{i}<P_{i}^{r e f} \\
0 & P_{i} \leq P_{i}^{r e f}
\end{array}\right.
$$

where $P_{i}^{\text {ref }}$ is the reference pressure necessary to satisfy the required demand $q_{i}^{\text {req }}, P_{i}^{\text {min }}$ is the pressure below which no water can be supplied, $\alpha$ (typically 0.5 ) is the exponent of the pressure-demand relationship, $P_{i}$ is the current pressure at node $i$.

(1) Volumetric efficiency $\left(\eta_{v}\right)$; One of the most important ratios among the system's efficiency indicators is volumetric performance. It is defined as the relationship 
between the registered volume $V_{\text {Reg }}$ and the total volume $V_{\text {Tot }}$ contributed in the same reference period [102]:

$$
\eta_{v}=\frac{V_{\text {Reg }}}{V_{T o t}}
$$

(2) Performance Indicators for Water Supply Services; International water association (IWA) provides performance indicators of water supply systems to compare the management of water losses, these are (i) Water losses and real losses as a \% of system input volume; (ii) Water losses per house connection and $\mathrm{km}$ of mains per day (density of connections $<20$ per $\mathrm{km}$ of mains), and (iii) Infrastructure Leakage Index (ILI) [103].

(3) Infrastructure Leakage Index (ILI); The ILI is a measure of how well a distribution network is managed (maintained, repaired, rehabilitated, etc.) for the control of real losses, at the current operating pressure. It is the ratio of the Current Annual volume of Real Losses (CARL) to Unavoidable Annual Real Losses (UARL) [104].

$$
I L I=\frac{C A R L}{U A R L}
$$

(4) Unavoidable Annual Real Losses (UARL); UARL is a useful concept as it can be used to predict the lowest technically annual real losses for any combination of mains length $(18 \mathrm{~L} / \mathrm{km}$ mains/day/meter of pressure), number of connections $0.8 \mathrm{~L} /$ service connection/day/meter of pressure), customer meter location and average operating pressure $(25 \mathrm{~L} / \mathrm{km} /$ day $/ \mathrm{m}$ of pressure) assuming that the system is in good condition with high standards for the management of real losses [105].

(5) Absolute annual consumed energy (IAAE); this index is sum of the total active consumed energy in the network subtracted by the sum of the total energy recovered in the network, the units are $\mathrm{kWh} /$ year [106].

(6) Absolute consumed energy per unit volume (IAEFW); Ratio between IAAE and the total volume of water introduced in the network, the units are $\mathrm{kWh} / \mathrm{m}^{3}$ [107].

\section{Results}

\subsection{Case Studies}

To observe the different methodologies applied to real cases of water distribution networks in different parts of the world, this research analyzed 45 case studies, as shown in Table 6.

Table 6. Information of the studied cases.

\begin{tabular}{cccccccc}
\hline ID & Case Study & Year & Ref & ID & Case Study & Year & Ref \\
\hline 1 & Skiathos, Greece & 2020 & {$[51]$} & 24 & Zarqa, Jordan & 2020 & {$[70]$} \\
2 & Leicester, UK & 2012 & {$[52]$} & 25 & Zarqa, Sana'a, Yemen & 2020 & {$[70]$} \\
3 & Benevento, Italy & 2017 & {$[55]$} & 26 & Mwanza, Tanzania & 2020 & {$[70]$} \\
4 & Pretoria, South Africa & 2017 & {$[29]$} & 27 & Mutarea, Zimbabwe & 2006 & {$[47]$} \\
5 & Polokwane, South Africa & 2019 & {$[54]$} & 28 & Skopje, Macedonia & 2011 & {$[108]$} \\
6 & Villarreal, Spain & 2014 & {$[109]$} & 29 & Pittsburgh, Pensilvania & 2005 & {$[110]$} \\
7 & Guayaquil, Ecuador & 2015 & {$[46]$} & 30 & Azogues, Ecuador & 2019 & {$[13]$} \\
8 & Antalya, Turkey & 2017 & {$[50]$} & 31 & Mankessim, Ghana & 2014 & {$[74]$} \\
9 & Konyaalti, Turkey & 2012 & {$[44]$} & 32 & Rzesów, Poland & 2019 & {$[1]$} \\
10 & Valencia, Spain & 2015 & {$[53]$} & 33 & Gorino Ferrarese, Italy & 2021 & {$[48]$} \\
11 & Palermo, Italy & 1999 & {$[56]$} & 34 & Salzburg, Austria & 2011 & {$[111]$} \\
12 & Nagpur, India & 2016 & {$[45]$} & 35 & Belgium & 2014 & {$[112]$} \\
13 & Nagpur, India & 2016 & {$[45]$} & 36 & Dryanovo, Bulgaria & 2014 & {$[112]$} \\
14 & London, UK & 1989 & {$[57]$} & 37 & Pula, Croatia & 2014 & {$[112]$} \\
15 & London, UK & 1989 & {$[57]$} & 38 & Lemesos, Cyprus & 2013 & {$[112]$} \\
\hline
\end{tabular}


Table 6. Cont.

\begin{tabular}{|c|c|c|c|c|c|c|c|}
\hline ID & Case Study & Year & Ref & ID & Case Study & Year & Ref \\
\hline 16 & Nourhan Samir, Egypt & 2017 & [16] & 39 & Odense, Denmark & 2013 & [112] \\
\hline 17 & C-Town & 2015 & [113] & 40 & England & 2013 & [112] \\
\hline 18 & Verona, Italy & 2019 & [58] & 41 & Bordeaux, France & 2012 & [112] \\
\hline 19 & Udine, Italy & 2014 & [114] & 42 & Munich, Germany & 2014 & [112] \\
\hline 20 & Patras, Greece & 2016 & [115] & 43 & Italy & 2010 & [112] \\
\hline 21 & $\begin{array}{c}\text { Case I-San Gregorio, } \\
\text { México }\end{array}$ & 2014 & {$[70]$} & 44 & Lisbon, Portugal & 2014 & [112] \\
\hline 22 & $\begin{array}{c}\text { Case II-San Gregorio, } \\
\text { México }\end{array}$ & 2014 & [70] & 45 & Scottish, UK & 2014 & [112] \\
\hline 23 & Drama, Greece & 2016 & [70] & & & & \\
\hline
\end{tabular}

Relevant information from the distribution networks was extracted from each case (Table 7) such as location, annual injected volume, mean operating pressure, leakage percentage, leak calculation method, calibration method.

Table 7. Information from case studies.

\begin{tabular}{|c|c|c|c|c|c|c|}
\hline ID Case & $\begin{array}{c}\text { Leakage } \\
(\%)\end{array}$ & $\begin{array}{c}\text { Average } \\
\text { Pressure (m) }\end{array}$ & $\begin{array}{l}\text { Annual Volume } \\
\text { Consumed }\left(\mathrm{m}^{3}\right)\end{array}$ & $\begin{array}{c}\text { Energy Consumed } \\
\text { per } \mathrm{m}^{3} \text { Injected } \\
\left(\mathrm{kWh} / \mathrm{m}^{3}\right)\end{array}$ & $\begin{array}{c}\text { Annual } \\
\text { Consumption } \\
(\mathbf{k W h})\end{array}$ & $\begin{array}{c}\text { Annual Energy } \\
\text { Lost by Leaks } \\
(\mathrm{kWh})\end{array}$ \\
\hline 1 & 57.56 & 54 & 33,016 & 0.15 & 115,093 & 66,252 \\
\hline 2 & 51.00 & 93 & 629,552 & 0.25 & 325,600 & 166,056 \\
\hline 3 & 12.03 & 50 & 807,216 & 0.14 & $1,250,363$ & 150,387 \\
\hline 4 & 25.00 & 63 & $12,772,080$ & 0.17 & $2,923,529$ & 730,882 \\
\hline 5 & 27.16 & 70 & $27,899,748$ & 0.19 & $7,306,457$ & $1,984,580$ \\
\hline 6 & 3.05 & 60 & $2,332,019$ & 0.16 & 393,260 & 11,975 \\
\hline 7 & 23.00 & 55 & 320,397 & 0.15 & 62,363 & 14,343 \\
\hline 8 & 34.94 & 45 & $1,436,640$ & 0.12 & 268,653 & 93,873 \\
\hline 9 & 34.38 & 47 & 513,336 & 0.13 & 101,834 & 35,010 \\
\hline 10 & 31.37 & 40 & $1,277,500$ & 0.11 & 202,904 & 63,656 \\
\hline 11 & 45.60 & 41 & $3,190,939$ & 0.11 & 659,074 & 300,538 \\
\hline 12 & 15.00 & 40 & $5,361,120$ & 0.11 & 687,485 & 103,123 \\
\hline 13 & 15.00 & 40 & $7,505,568$ & 0.11 & 962,479 & 144,372 \\
\hline 14 & 14.90 & 59 & $11,003,226$ & 0.16 & $2,068,799$ & 308,251 \\
\hline 15 & 17.20 & 34 & $4,047,330$ & 0.09 & 452,881 & 77,895 \\
\hline 16 & 54.00 & 30 & 169,243 & 0.08 & 30,077 & 16,242 \\
\hline 17 & 26.05 & 40 & $5,370,085$ & 0.11 & 791,534 & 206,194 \\
\hline 18 & 23.92 & 65 & $1,577,530$ & 0.18 & 367,280 & 87,860 \\
\hline 19 & 28.31 & 31 & $8,842,478$ & 0.09 & $1,052,511$ & 297,966 \\
\hline 20 & 55.00 & 30 & $9,855,000$ & 0.08 & $1,790,325$ & 984,679 \\
\hline 21 & 28.45 & 40 & 251,605 & 0.11 & 38,328 & 10,903 \\
\hline 22 & 34.41 & 40 & 308,260 & 0.11 & 51,230 & 17,630 \\
\hline 23 & 19.80 & 30 & $9,358,600$ & 0.08 & 953,945 & 188,879 \\
\hline 24 & 63.27 & 50 & $24,588,597$ & 0.14 & $9,122,084$ & $5,771,888$ \\
\hline 25 & 38.24 & 50 & $13,766,774$ & 0.14 & $3,037,055$ & $1,161,332$ \\
\hline 26 & 46.06 & 50 & $16,231,357$ & 0.14 & $4,100,160$ & $1,888,637$ \\
\hline 27 & 57.00 & 77 & $18,049,250$ & 0.21 & $8,750,213$ & $4,987,622$ \\
\hline 28 & 52.50 & 40 & 426,919 & 0.11 & 97,967 & 51,432 \\
\hline 29 & 40.00 & 114 & 862,194 & 0.31 & 446,401 & 178,560 \\
\hline 30 & 46.86 & 75 & 157,946 & 0.20 & 60,746 & 28,465 \\
\hline 31 & 12.00 & 56 & 430,151 & 0.15 & 74,592 & 8951 \\
\hline 32 & 30.00 & 40 & $2,571,680$ & 0.11 & 400,623 & 120,187 \\
\hline 33 & 13.33 & 30 & 81,994 & 0.08 & 7734 & 1031 \\
\hline 34 & 5.57 & 46 & $12,210,000$ & 0.13 & $1,620,776$ & 90,252 \\
\hline 35 & 20.70 & 38 & $130,180,000$ & 0.10 & $16,998,768$ & $3,518,629$ \\
\hline
\end{tabular}


Table 7. Cont.

\begin{tabular}{|c|c|c|c|c|c|c|}
\hline ID Case & $\begin{array}{l}\text { Leakage } \\
(\%)\end{array}$ & $\begin{array}{c}\text { Average } \\
\text { Pressure (m) }\end{array}$ & $\begin{array}{l}\text { Annual Volume } \\
\text { Consumed }\left(\mathrm{m}^{3}\right)\end{array}$ & $\begin{array}{l}\text { Energy Consumed } \\
\text { per } \mathrm{m}^{3} \text { Injected } \\
\left(\mathrm{kWh} / \mathrm{m}^{3}\right)\end{array}$ & $\begin{array}{c}\text { Annual } \\
\text { Consumption } \\
(\mathbf{k W h})\end{array}$ & $\begin{array}{c}\text { Annual Energy } \\
\text { Lost by Leaks } \\
\text { (kWh) }\end{array}$ \\
\hline 36 & 74.96 & 42 & $1,780,000$ & 0.11 & 813,740 & 610,019 \\
\hline 37 & 22.55 & 40 & $6,630,000$ & 0.11 & 933,040 & 210,370 \\
\hline 38 & 23.22 & 40 & $10,120,000$ & 0.11 & $1,436,620$ & 333,540 \\
\hline 39 & 47.00 & 30 & 530,009 & 0.08 & 81,751 & 38,423 \\
\hline 40 & 17.54 & 44 & $330,660,000$ & 0.12 & $48,079,900$ & $8,433,766$ \\
\hline 41 & 15.87 & 37 & $40,010,000$ & 0.10 & $4,795,237$ & 76,1229 \\
\hline 42 & 13.33 & 60 & $91,000,000$ & 0.16 & $17,167,500$ & $2,289,000$ \\
\hline 43 & 24.71 & 44 & $33,830,000$ & 0.12 & $5,387,107$ & $1,330,890$ \\
\hline 44 & 12.99 & 51 & $26,524,047$ & 0.14 & $4,236,514$ & 550,334 \\
\hline 45 & 58.69 & 45 & $147,752,776$ & 0.12 & $43,854,719$ & $25,736,535$ \\
\hline
\end{tabular}

The FAVAD method is the most used in research analyzed, there is an extensive literature of its application in real case studies where the calibration methods applied in the networks are shown. With the information extracted from each case study, key performance indicators (KPIs) such as volumetric efficiency of the system, the volume of water lost annually and its associated cost, the energy lost in $\mathrm{kWh}$ for each $\mathrm{m}^{3}$ injected and its cost was calculated.

\subsection{Influence of the Leakages in the KPI of the Water Systems}

Water leaks in distribution networks condition the quality and quantity of water for users. The existence of leaks increases the loss of water and the operating costs of the networks management because more energy is required in the flow to guarantee the minimum operating pressure.

For each of the case studies shown in Table 7, the following information was extracted: annual volume injected into the network, percentage of leaks, and mean pressure. The analysed data enabled the calculation of the following parameters: volumetric efficiency of the network, energy consumed for each cubic meter of water injected into the network, annual energy consumption, energy lost due to leaks, and the associated costs due to loss of water and energy.

As mentioned above, volumetric efficiency is the ratio of recorded volume to total volume over a period. For the 45 case studies, the distribution corresponding to the volumetric efficiency is shown in Figure 2a resulting in a mean of $\eta=0.73$ and quartiles of $\eta=0.53$ and $\eta=0.83$. Figure $2 \mathrm{~b}$ shows the leakage percentage in the distribution networks with an average leakage value of $27 \%$ and quartiles of $17 \%$ and $46 \%$.
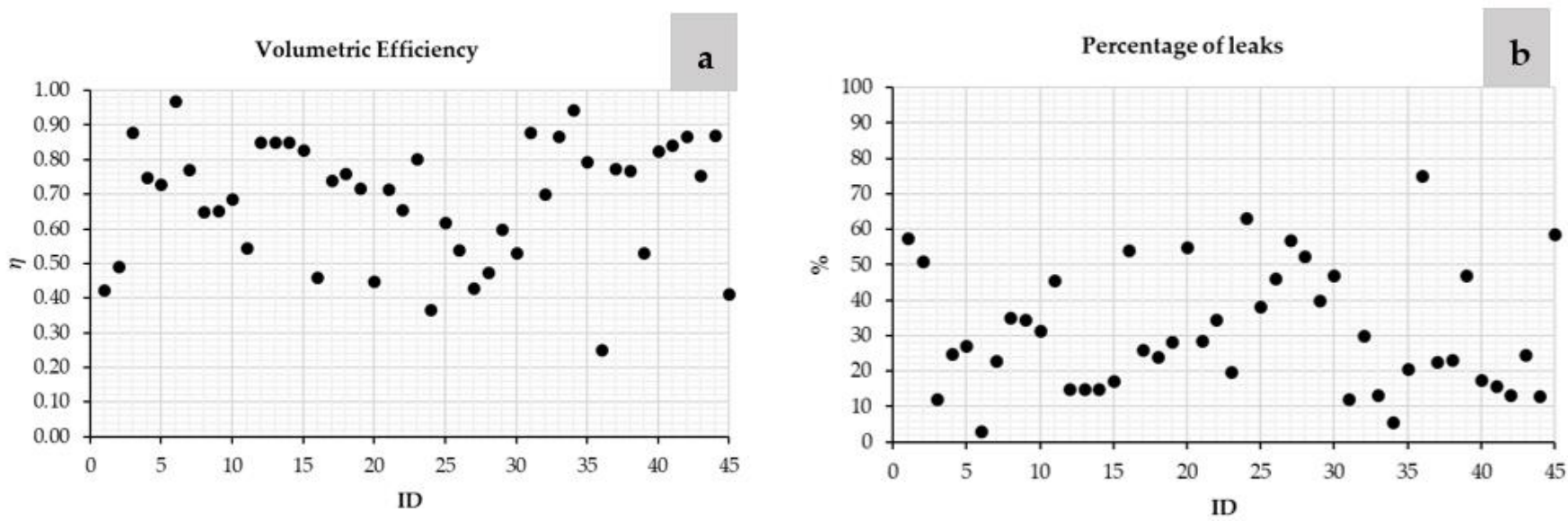

Figure 2. Volumetric efficiency (a) and percentage of leaks (b). 
Each of the distribution networks has different physical characteristics, such as diameters, lengths, valves, pressures, and flow rates. The configuration of each network will depend on the design conditions, this will make each of them operate differently, some of the networks transport the flow by gravity and others under pressure using pumps.

The average pressure of each distribution network was obtained as shown in Figure 3a. Its average value was $44 \mathrm{~m}$ w.c. and the quartiles were 40 and $45 \mathrm{~m}$ w.c. Two atypical values are observed that correspond to networks where their topography had high slopes. Figure $3 \mathrm{~b}$ shows the annual volume injected into the network. The average value was $7.26 \mathrm{Hm}^{3}$ and the quartiles were 1.21 and $24.24 \mathrm{Hm}^{3}$. There were 5 cases above $50 \mathrm{Hm}^{3}$. These reached annual values of up to $400 \mathrm{Hm}^{3}$.
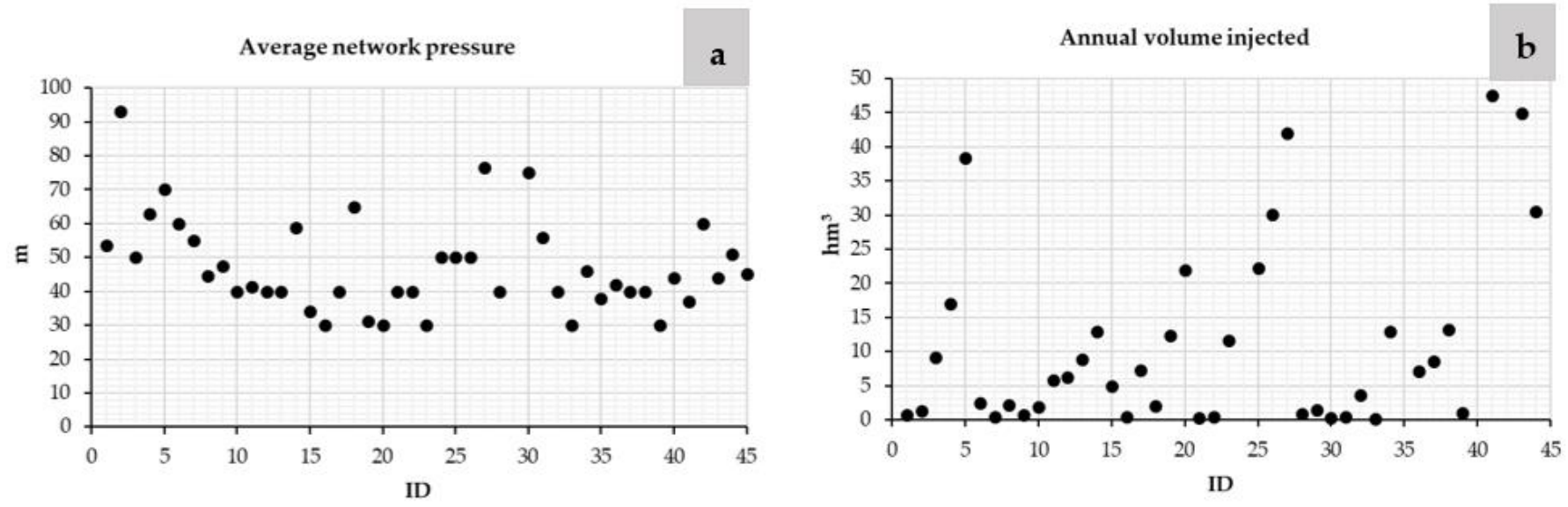

Figure 3. Average pressure (a) and annual flow injected into the network (b).

The average pressure of each case study was related to the percentage of leaks and the volumetric efficiency of the system. The ratio between the average pressure and the leakage percentage is shown in Figure 4a. The values are between 50 and 500, being the average equal to 243 . Figure $4 \mathrm{~b}$ shows the relationship between the average pressure of the network and the volumetric performance. This ratio shows values between 40 and 200, being the average value equal to 78 m.w.c.
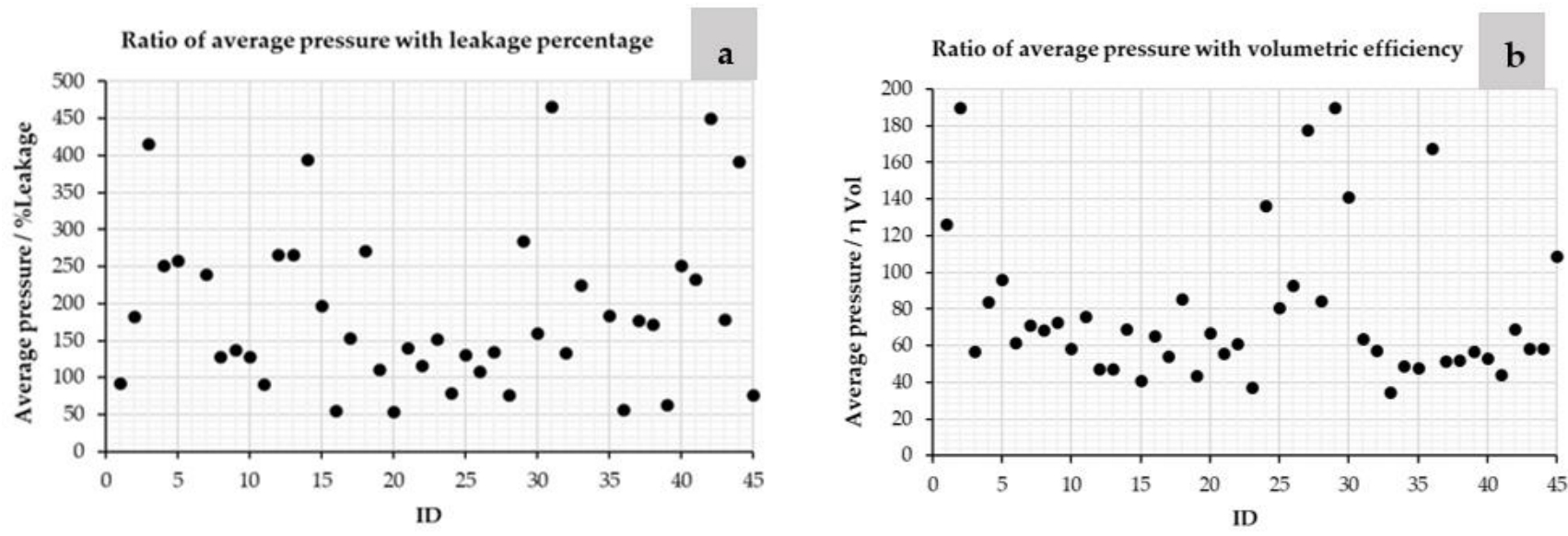

Figure 4. Ratio between average pressure with leakage percentage (a) and volumetric efficiency (b).

In energy terms, the value of average pressure and flow injected into the networkenabled to estimate the average energy consumption of the network per unit volume $\left(\mathrm{kWh} \cdot \mathrm{m}^{-3}\right)$. Subsequently, when the percentage of leaks associated with each network was known, the annual unit energy lost was determined [116]. 
Figure 5a shows the average value of the energy lost for the case studies is $178,600 \mathrm{kWh}$ with quartiles 60,600 kWh and 817,100 kWh. Above 1,000,000 kWh there were 10 cases that reached values of up to $10 \mathrm{GWh}$.

Once the percentage of leakage from the network was known, the water lost in the network was calculated. The average value of the annual volume leaked was $1,325,000 \mathrm{Hm}^{3}$, being the quartiles between $470,400 \mathrm{Hm}^{3}$ and 7,793,000 $\mathrm{Hm}^{3}$. Figure 5 b shows the energy lost for each $\mathrm{m}^{3}$ of water injected into the distribution networks. The average value was $0.12 \mathrm{kWh} / \mathrm{m}^{3}$, being the quartiles between 0.11 and $0.15 \mathrm{kWh} / \mathrm{m}^{3}$.
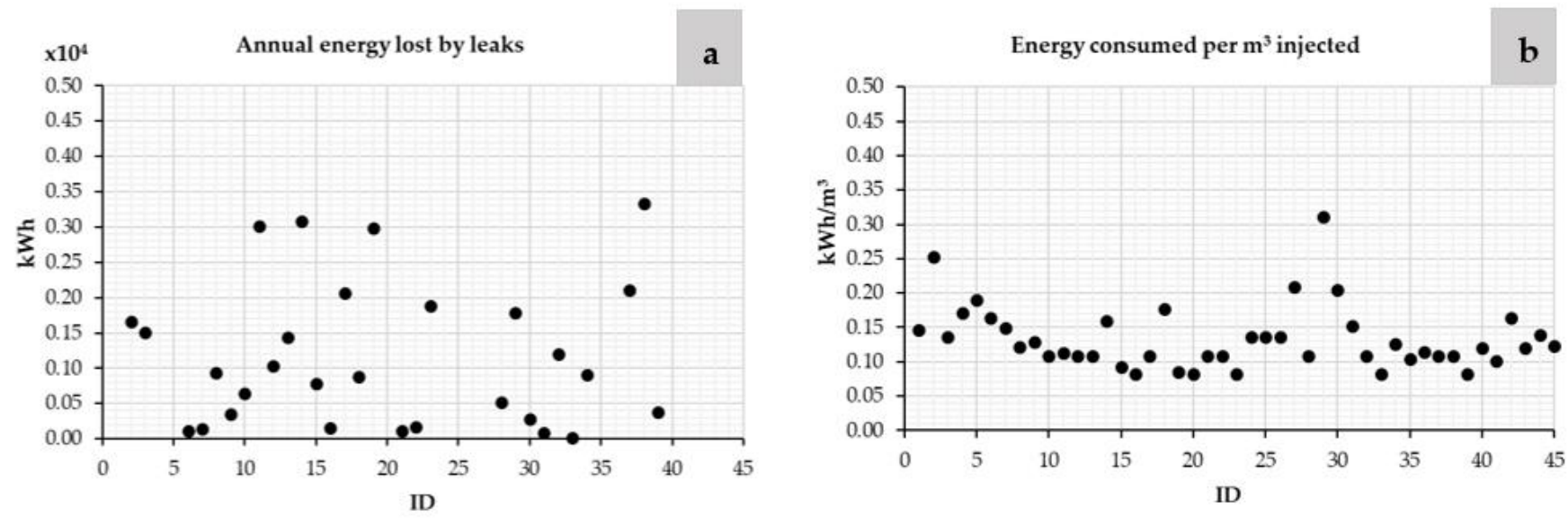

Figure 5. Annual energy lost by leaks (a) and energy consumed per $\mathrm{m}^{3}$ injected (b).

To estimate the lost economic value of energy and water, the following rates were established: for water $1.9 € / \mathrm{m}^{3}$ and energy $0.11 € / \mathrm{kWh}$. Once the value of the volume of water lost in leaks had been calculated, its average annual cost corresponding to a value of $€ 2,097,000$ with quartiles $€ 885,600$ and $€ 11,180,000$ as shown in Figure 6a. Above $€ 10,000,00013$ cases reached values of up to $€ 100,000,000$ Similarly, the average annual energy cost lost is $€ 121,400$ with quartiles $€ 51,270$ and $€ 647,400$ as shown in Figure $6 \mathrm{~b}$.
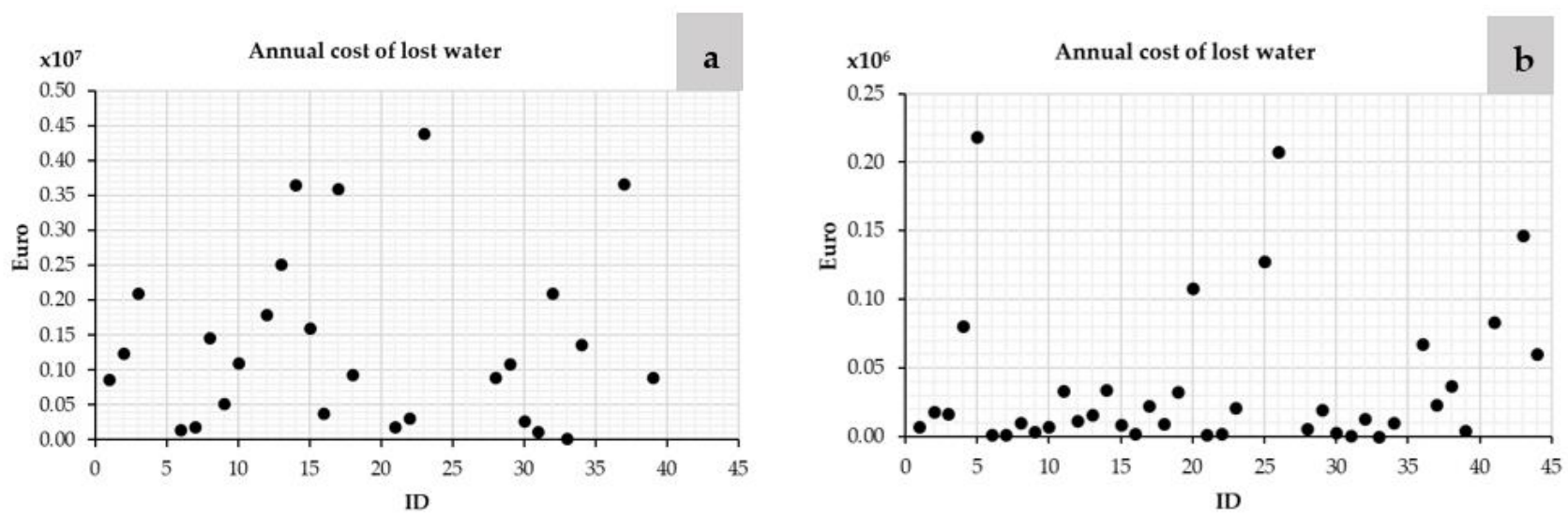

Figure 6. The annual cost of lost water (a) and the annual cost of lost water (b).

The leak calculation methods such as BABE, MNF, and water balance were applied and compared in different case studies, which were defined by $[117,118]$. The analysis was established to determine the real water loss in million $\mathrm{m}^{3} /$ year as shown in Table 8 . 
Table 8. Leak method comparison.

\begin{tabular}{ccccc}
\hline Method & Zarqa, Jordan & Sana'a, Yemen & Mwanza, Tanzania & Gavankola, Iran \\
\hline Water Balance & 40 & 7.1 & 12.2 & - \\
\hline MNF & 16.2 & - & 12.2 & 34.9 \\
\hline BABE & 4.2 & 0.4 & 5.8 & 39.4 \\
\hline
\end{tabular}

Using the MNF and BABE methods, the average of real water loss in the studied region was calculated at $28 \%$ and $37 \%$, respectively. According to the results of the $\mathrm{BABE}$ method, the highest leakage values were related to the reported bursts and the background leaks from connections [118]. The water balance method is the difference between the volume of water injected into the network concerning the volume of water consumed. The result of the difference corresponds to leaks, where it is observed that the results obtained are greater than those obtained with the methods calculation of BABE and MNF leaks.

Applying each method requires verification for the factors and as sumptions in each method and their sensitivities and uncertainties. Conducting MNF analysis in one or several small areas in the network (DMAs) and extrapolating it to the entire network might be justifiable in some cases, but it is not very rational because every DMA differs in terms of the mains length, service connections, pressure, and burst frequencies. The component analysis of the leakage method (BABE) remains the only way to break down the leakage into subcomponents, enabling the water utilities to understand the nature and behaviour of the leakage in their systems. However, the component analysis of the leakage analyses only a small portion of the total leakages [117].

\subsection{Pump Working as Turbine Using Leakages Models}

Micro and mini-hydropower generators can be installed in water distribution systems to ensure both pressure control for leakage reduction and energy production [119]. Jain [26] in his research, shows a wide state of the art on pumps working as turbines, from their selection, methods, and cases of application. In water distribution networks (WDNs), the PATs can be used instead of pressure-reducing valves (PRVs) for both pressure reduction and energy production [27].

Reference [106] showed a table with the advantages and disadvantages of installing PATs in the distribution system compared to other methods that reduce pressure and leakage. Ref. [120] implemented a model through Simulink in Matlab to reduce the pressure in the distribution networks through the installation of PATs. This model was implemented in a real case study by [121].

Reference [27] mentioned the importance of the implementation of PATs for pressure management, benefiting the reduction of leaks in the distribution network. In the applied case, this research shows that the proposed optimization model allows a leakage reduction of $26.6 \%$ and an energy recovery of $182.15 \mathrm{kWh} /$ day.

Reference [122] showed a methodology for the optimal location of PAT within a water distribution network to produce energy and reduce leakage. The total amount of saved water has been accounted as $275,870 \mathrm{~m}^{3}$ /year while the net present value (NPV) resulted as $€ 75,936$. Reference [50] estimated a reduction in pressure of approximately 1 bar and a flow reduction of the order of $50 \mathrm{~m}^{3} / \mathrm{h}$ were achieved just after the operation of the PAT system in Antalya, Turkey. Reference [123] showed the possibility of optimally managing a water distribution system by reducing leaks and recovering energy. The study considered the installation of between 10 to 15 PATs in the network of the Sorrento Peninsula (Italy) that distributes water in a network of 90,000 users.

Reference [124] estimated that the installation of PATs represents a $45 \%$ reduction in water savings equivalent to $7000 \mathrm{~m}^{3}$ /year. An optimization method is proposed that uses an objective function for the reduction of leaks and energy production by implementing PATs in a distribution system [125]. This study proposed a new preliminary model to optimize the location of PATs in a water distribution network. The optimization aims 
to determine the best number and location of turbines to reduce pressure, thus water leakage, and produce energy. The implementation of 6 PATs in the case study would mean a water-saving of $929 \mathrm{~m}^{3} /$ day and an average power of 14.53kW. Reference [126] proposed a method for the optimal location of PAT through a mixed integer non-linear program (MINLP). Using the model in the case study, it achieves an average water reduction of $7.88 \mathrm{~L} / \mathrm{s}$ and an energy recovery of $1958 \mathrm{kWh}$ /day.

The Leakage Control and Energy Recovery Using Variable Speed Pumps as Turbines in two water distribution networks are proposed by [127]. It demonstrated a methodology through flow diagrams for the selection of PATs and different combinations of PATs applications operating constantly and variably, obtaining as results leakage reductions and energy recovery.

Table 9 shows the influence of the installation of PATs in various case studies, where relevant information such as flow, pressure, leakage percentage, annual energy and water recovered per installation were extracted. It is observed that for all the case studies the implementation of PATs supposes a reduction of leaks in the distribution network Because not all the case studies show the percentage of total network leakage, $27 \%$ leakage is adopted as the average value since this was the value obtained in the leakage study cases previously analyzed.

Table 9. Information extracted from case studies.

\begin{tabular}{|c|c|c|c|c|c|c|c|c|}
\hline Reference & ID & Flow (L/s) & $\mathbf{H}(\mathrm{m})$ & $\begin{array}{c}\text { Annual Energy } \\
\text { Recovered by } \\
\text { Installing PATs } \\
\text { (kWh/year) }\end{array}$ & $\begin{array}{c}\text { Annual Volume } \\
\text { Recovered by } \\
\text { Use of PATs } \\
\left(\mathrm{m}^{3}\right)\end{array}$ & $\begin{array}{l}\text { Leakage } \\
\text { Reduction } \\
\text { by Use of } \\
\text { PATs (\%) }\end{array}$ & $\begin{array}{l}\eta_{v} \text { before } \\
\text { Installing } \\
\text { PATs }\end{array}$ & $\begin{array}{c}\eta_{v} \text { after } \\
\text { Installing } \\
\text { PATs }\end{array}$ \\
\hline & & & & & & 21 & & \\
\hline [102] & 46 & 29 & 59 & 43,800 & - & 20 & - & - \\
\hline [102] & 47 & 74 & 54 & 87,600 & - & 32 & - & - \\
\hline [102] & 48 & 19 & 67 & 39,420 & - & 18 & - & - \\
\hline [102] & 49 & 33 & 55 & 43,800 & - & 21 & - & - \\
\hline [102] & 50 & 19 & 63 & 35,040 & - & 29 & - & - \\
\hline [102] & 51 & 14 & 71 & 26,280 & - & 65 & - & - \\
\hline [102] & 52 & 31 & 65 & 52,560 & - & 21 & - & - \\
\hline [128] & 53 & 29 & 21 & 28,470 & 22,813 & 63 & 0.73 & 0.90 \\
\hline [128] & 54 & 183 & 33 & 169,360 & $1,634,590$ & 52 & 0.73 & 0.87 \\
\hline [128] & 55 & 72 & 36 & 130,305 & 98,185 & 63 & 0.73 & 0.90 \\
\hline [27] & 56 & 302 & 61 & 55,626 & $2,475,059$ & 26 & 0.73 & 0.80 \\
\hline [27] & 57 & 212 & 39 & 71,876 & 667,554 & 10 & 0.73 & 0.76 \\
\hline [27] & 58 & 314 & 50 & 66,485 & $1,829,359$ & 19 & 0.73 & 0.78 \\
\hline [120] & 59 & 187 & 70 & 54,985 & - & - & - & - \\
\hline [122] & 60 & 110 & 45 & 125,213 & 339,085 & 10 & 0.73 & 0.76 \\
\hline [125] & 61 & 110 & 45 & 113,880 & 328,865 & 9 & 0.73 & 0.75 \\
\hline [126] & 62 & 350 & 45 & 714,670 & 248,504 & 3 & 0.73 & 0.74 \\
\hline
\end{tabular}

Pressure Management (PM), which is usually the best way to reduce the Non-Revenue Water (NRW) level in a water distribution network, is achieved mainly by forming (dividing the network into several) District Metered Areas (DMAs). In the city of Kozani (Greece), [102] analyzed the possibility of implementing PATs in the water distribution system. The implementation of PATs in the case study would suppose a reduction of leaks between $20 \%$ and $40 \%$ approximately. The reduction of leakages decreased $325,500 \mathrm{kWh}$ of lost energy. The investigation shows the possible combinations of PATs with different installed power values from 5 to $12 \mathrm{~kW}$.

Figure 7a shows the influence of the installation of PATs in a WDN. Figure 7a shows the reduction of the leakage flow after the installation of PATs varies from 18 to $65 \%$, while Figure $7 \mathrm{~b}$ shows the pressure reduction with values from 29 to $55 \%$. 

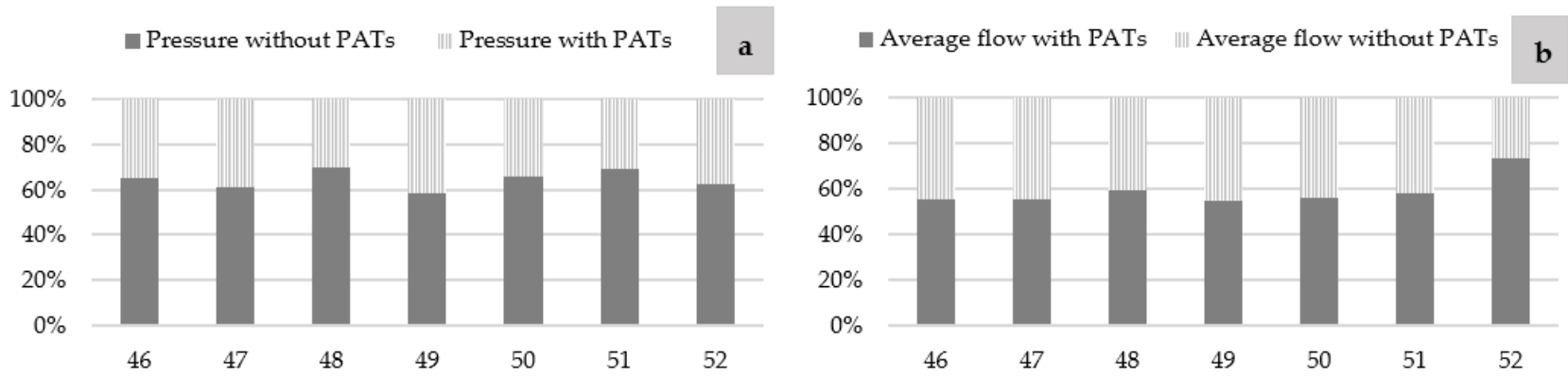

Figure 7. Influence of the installation of PATs. Comparison of network pressure by the installation of PATs (a); Comparison of flow injected into the network by the installation of PATs (b).

Once the leakage value was known, the volumetric efficiency was calculated, which was 0.73 before the consideration of the PATs systems. For all the case studies, the reduction of leaks significantly increases the volumetric performance after installing PATs in the distribution network.

Figure 8 shows the efficiency indicators calculated in water distribution networks with the installation of PATs for the selected case studies. Figure 8a shows the annual energy consumption, the average value of the cases is $93,000 \mathrm{kWh} /$ year. Figure $8 \mathrm{~b}$ shows the energy consumed for each $\mathrm{m}^{3}$ injected into the network with an average value of $0.10 \mathrm{kWh} / \mathrm{m}^{3}$.
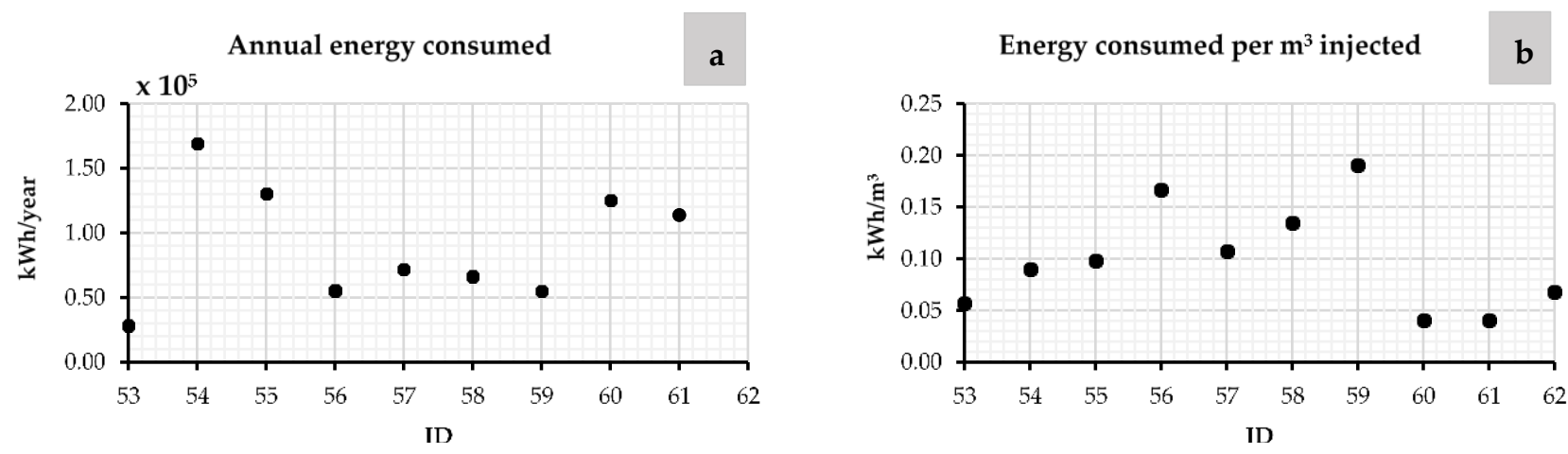

Figure 8. Efficiency indicators in networks with PATs installed. Annual Energy consumed (a); Energy consumed per $\mathrm{m}^{3}$ injected (b).

\subsection{Energy Index Calculation Case Study}

For each of the study cases, the energy indices were calculated. The energy indices determined in Table 10 are: absolute energy consumed annually (IAAE) in $\mathrm{kWh} /$ year, recovered energy (IER) in $\mathrm{kWh}$ /year, percentage of recoverable energy (ERP) in \%, absolute energy consumed per unit volume (IAEFW) in $\mathrm{kWh} / \mathrm{m}^{3}$. Besides, a new index was proposed to consider the influence of the PATs system in the reduction of leakage. This index, called index reduction leakage flow as a function of generating power (IRLGP), shows the ratio between reduction of the leakage volume for each installed power. The units of this index are $\mathrm{m}^{3} / \mathrm{kW}$. 
Table 10. Calculable energy indices with available data.

\begin{tabular}{ccccccc}
\hline Reference & ID & $\begin{array}{c}\text { IAAE } \\
(\mathbf{k W h} / \text { Year })\end{array}$ & $\begin{array}{c}\text { IER } \\
\mathbf{( k W h / Y e a r )}\end{array}$ & $\begin{array}{c}\text { ERP } \\
\mathbf{( \% )}\end{array}$ & $\begin{array}{c}\text { IEFW } \\
\left.\mathbf{( k W h} / \mathbf{m}^{3}\right)\end{array}$ & $\begin{array}{c}\text { IRLGP } \\
\left(\mathbf{m}^{\mathbf{3}} \mathbf{/ k W}\right)\end{array}$ \\
\hline$[128]$ & 53 & 52,335 & 28,470 & 54 & 0.06 & 8 \\
{$[128]$} & 54 & 518,965 & 169,360 & 3 & 0.09 & - \\
{$[128]$} & 55 & 222,745 & 130,305 & 58 & 0.10 & 4 \\
{$[27]$} & 56 & $1,583,106$ & 55,626 & 4 & 0.17 & 2 \\
{$[27]$} & 57 & 710,516 & 71,876 & 10 & 0.11 & 16 \\
{$[27]$} & 58 & $1,349,189$ & 66,485 & 5 & 0.14 & 13 \\
{$[120]$} & 59 & $1,124,897$ & 54,985 & 5 & 0.19 & - \\
{$[122]$} & 60 & 141,794 & 125,213 & 29 & 0.12 & 5 \\
{$[125]$} & 61 & 141,794 & 113,880 & 27 & 0.12 & 5 \\
{$[126]$} & 62 & 751,937 & 714,670 & 53 & 0.12 & 4 \\
\hline
\end{tabular}

Annual energy consumption in the analyzed distribution networks ranges from 141,794 to $1,583,106 \mathrm{kWh}$. By installing PATs in the distribution networks, annual energy recovery values are obtained from 28,470 to $714,670 \mathrm{kWh}$. Using the IAAE and IER values, the ERP index was determined, resulting in recovery values from 3 to $58 \%$.

The relationship of the annual volume of water injected into the network concerning IAAE allowed the calculation of the IEFW index. This shows values between 0.06 and $0.19 \mathrm{kWh} / \mathrm{m}^{3}$. The difference between the total leaked volume in the network compared to the volume recovered by using PATs is used to calculate the reduction of the volume leaked by the installation of PATs. Considering the relationship between the reduced volume and the annual energy recovery, the IRLGP index was calculated, which shows values between 2 and $16 \mathrm{~m}^{3} / \mathrm{kW}$.

\section{Conclusions}

Several leakage methods have been implemented in distribution networks, and for each formulation it was possible to extract its main characteristics, advantages, and disadvantages. The FAVAD method is the most widely used in the case of studies for estimating leaks in water distribution networks. It was evidenced that through experimentation and estimates different values of leakage exponents have been determined for each type of formulation depending on the type of leak, age and pipe material.

Different methods for calibrating leak models are proposed by various authors, with genetic algorithms being the most widely implemented in the models. The analysis carried out on sixty-two case studies allowed the extraction of relevant information from the network to calculate and compare various efficiency indices such as volumetric performance, percentage of leaks, energy lost due to leaks, annual energy consumption for each cubic meter injected into the network and costs for loss of water and energy.

The analyzed case studies, which had installed PATs systems showed the implementation of micro-hydropower systems causes a considerable reduction in the pressure of the network, reducing the level of leaks between $4 \%$ and $63 \%$, while the recovered energy was estimated between 28,470 and $714,670 \mathrm{kWh} /$ year.

To improve the sustainable development goals, the use of efficiency indicators are an important tool for the analysis and management of water distribution networks. In this line, the researchers analyzed the variation of the different indicators in 62 cases studies in energy, economic and environmental terms deeply. The proposal of sustainable measurements should start, knowing the state of the water system. The installation of PATs in the distribution networks is a solution to reduce the volume of leakage and an opportunity to recover clean energy. The analysis of the PATs systems should be considered when leakages are considered. The influence of the leakages can cause differences in the selection, operation and regulation of the recovery machines and it should be considered by water managers in energy optimization procedures as well as the energy analyses. Besides, the installation of PATs systems in real case studies should consider the significance of the leakages in the operation of these recovery machines. This research shows the need 
to apply the analysis of indicators for the improvement of the energy analysis. Future works should develop around this topic. This new research should develop optimization procedures in which the leakages will be considered as a decision variable. The analysis of the leakages will include the influence of these water losses in the selection and regulation of the PATs systems, and therefore, its impact in the recovered energy.

Author Contributions: Conceptualization, P.A.L.-J. and M.P.-S.; methodology, C.A.M.Á. and F.-J.S.R.; software, writing—original draft preparation, C.A.M.Á. and M.P.-S.; writing—review and editing, M.P.-S. and P.A.L.-J.; visualization M.P.-S.; supervision, P.A.L.-J. All authors have read and agreed to the published version of the manuscript.

Funding: This research received no external funding.

Institutional Review Board Statement: Not applicable.

Informed Consent Statement: Not applicable.

Data Availability Statement: Not applicable.

Conflicts of Interest: The authors declare no conflict of interest.

\section{References}

1. Rojek, I.; Studzinski, J. Detection and localization of water leaks in water nets supported by an ICT system with artificial intelligence methods as away forward for smart cities. Sustainability 2019, 11, 518. [CrossRef]

2. Farley, M. Leakage Management and Control; WHO: Geneva, Switzerland, 2001; pp. 1-98.

3. Öztürk, I.; Uyak, V.; Çakmakci, M.; Akça, L. Dimension of water loss through distribution system and reduction methods in Turkey. Int. Congr. River Basin Manag. 2007, 1, 22-24.

4. Maskit, M.; Ostfeld, A. Leakage Calibration of Water Distribution Networks. Procedia Eng. 2014, 89, 664-671. [CrossRef]

5. Germanopoulos, G. A technical note on the inclusion of pressure dependent demand and leakage terms in water supply network models. Civ. Eng. Syst. 1985, 2, 171-179. [CrossRef]

6. Adedeji, K.B.; Hamam, Y.; Abe, B.T.; Abu-Mahfouz, A.M. Towards Achieving a Reliable Leakage Detection and Localization Algorithm for Application in Water Piping Networks: An Overview. IEEE Access 2017, 5, 20272-20285. [CrossRef]

7. Meniconi, S.; Capponi, C.; Frisinghelli, M.; Brunone, B. Leak Detection in a Real Transmission Main through Transient Tests: Deeds and Misdeeds. Water Resour. Res. 2021, 57. [CrossRef]

8. Duan, H.-F.; Pan, B.; Wang, M.; Chen, L.; Zheng, F.; Zhang, Y. State-of-the-art review on the transient flow modeling and utilization for urban water supply system (UWSS) management. J. Water Supply Res. Technol. 2020, 69, 858-893. [CrossRef]

9. Ayati, A.H.; Haghighi, A.; Lee, P.J. Statistical Review of Major Standpoints in Hydraulic Transient-Based Leak Detection. J. Hydraul. Struct. 2019, 5. [CrossRef]

10. Modeling, N.; Leak, O.F.; On, E.; Behavior, T. Transient test-based technique for leak detection in outfall pipes. J. Water Resour. Plan. Manag. 1999, 125, 302-306.

11. Capponi, C.; Ferrante, M.; Zecchin, A.C.; Gong, J. Leak Detection in a Branched System by Inverse Transient Analysis with the Admittance Matrix Method. Water Resour. Manag. 2017, 31, 4075-4089. [CrossRef]

12. Adachi, S.; Takahashi, S.; Zhang, X.; Umeki, M.; Tadokoro, H. Estimation of Area Leakage in Water Distribution Networks: A Real Case Study. Procedia Eng. 2015, 119, 4-12. [CrossRef]

13. Garcia, F.; Avilés-Añazco, A.; Ordoñez-Jara, J.; Guanuchi-Quezada, C. Pressure management for leakage reduction using pressure reducing valves. Case study in an Andean City. Alex. Eng. J. 2019, 58, 1313-1326. [CrossRef]

14. Rajani, B.; Kleiner, Y. Comprehensive review of structural deterioration of water mains: Physically based models. Urban. Water 2001, 3, 151-164. [CrossRef]

15. Almandoz, J.; Cabrera, E.; Arregui, F.; Cobacho, R. Leakage Assessment through Water Distribution Network Simulation. J. Water Resour. Plan. Manag. 2005, 131, 458-466. [CrossRef]

16. Samir, N.; Kansoh, R.; Elbarki, W.; Fleifle, A. Pressure control for minimizing leakage in water distribution systems. Alex. Eng. J. 2017, 56, 601-612. [CrossRef]

17. Ulanicki, B.; Skworcow, P.; Ulanicki, B.; Skworcow, P. Why PRVs Tends to Oscillate at Low Flows. Procedia Eng. 2014, 89, 378-385. [CrossRef]

18. Abdelmeguid, H.; Skworcow, P.; Ulanicki, B. Mathematical modelling of a hydraulic controller for PRV flow modulation. J. Hydroinformatics 2011, 13, 374-389. [CrossRef]

19. Ali, M.E. Knowledge-Based Optimization Model for Control Valve Locations in Water Distribution Networks. J. Water Resour. Plan. Manag. 2015, 141, 04014048. [CrossRef]

20. Creaco, E.; Pezzinga, G. Multiobjective Optimization of Pipe Replacements and Control Valve Installations for Leakage Attenuation in Water Distribution Networks. J. Water Resour. Plan. Manag. 2015, 141, 04014059. [CrossRef] 
21. Meniconi, S.; Brunone, B.; Mazzetti, E.; Laucelli, D.B.; Borta, G. Hydraulic characterization and transient response of pressure reducing valves: Laboratory experiments. J. Hydroinformatics 2017, 19, 798-810. [CrossRef]

22. Meniconi, S.; Brunone, B.; Ferrante, M.; Mazzetti, E.; Laucelli, D.B.; Borta, G. Transient Effects of Self-adjustment of Pressure Reducing Valves. Procedia Eng. 2015, 119, 1030-1038. [CrossRef]

23. Ramos, H.M.; Borga, A. Pumps as turbines: An unconventional solution to energy production. Urban. Water 1999, 1, 261-263. [CrossRef]

24. Novara, D.; Carravetta, A.; McNabola, A.; Ramos, H.M. Cost Model for Pumps as Turbines in Run-of-River and In-Pipe Microhydropower Applications. J. Water Resour. Plan. Manag. 2019, 145, 04019012. [CrossRef]

25. De Marchis, M.; Fontanazza, C.; Freni, G.; Messineo, A.; Milici, B.; Napoli, E.; Notaro, V.; Puleo, V.; Scopa, A. Energy Recovery in Water Distribution Networks. Implementation of Pumps as Turbine in a Dynamic Numerical Model. Procedia Eng. 2014, 70, 439-448. [CrossRef]

26. Jain, S.V.; Patel, R.N. Investigations on pump running in turbine mode: A review of the state-of-the-art. Renew. Sustain. Energy Rev. 2014, 30, 841-868. [CrossRef]

27. Ebrahimi, S.; Riasi, A.; Kandi, A. Selection optimization of variable speed pump as turbine (PAT) for energy recovery and pressure management. Energy Convers. Manag. 2021, 227, 113586. [CrossRef]

28. Al-Washali, T.; Sharma, S.; Al-Nozaily, F.; Haidera, M.; Kennedy, M. Modelling the Leakage Rate and Reduction Using Minimum Night Flow Analysis in an Intermittent Supply System. Water 2018, 11, 48. [CrossRef]

29. Adedeji, K.B.; Hamam, Y.; Abe, B.T.; Abu-Mahfouz, A.M. Leakage Detection and Estimation Algorithm for Loss Reduction in Water Piping Networks. Water 2017, 9, 773. [CrossRef]

30. Laucelli, D.B.; Meniconi, S. Water distribution network analysis accounting for different background leakage models. Procedia Eng. 2015, 119, 680-689. [CrossRef]

31. Darsana, P.; Varija, K. Leakage detection studies for water supply systems-A review. Water Resour. Manag. 2018, 78, 141-150.

32. Guo, S.; Zhang, T.-Q.; Shao, W.-Y.; Zhu, D.Z.; Duan, Y.-Y. Two-dimensional pipe leakage through a line crack in water distribution systems. J. Zhejiang Univ. A 2013, 14, 371-376. [CrossRef]

33. Morales, E.; José, J.; Cabrera, E.; Cobacho, R. Método de los Caudales Minimos Nocturnos: Revisión De Sus Bases Científicas, Evaluación de Errores Potenciales y Propuestas Para su Mejora. Master's Thesis, Universitat Politècnica de València, Valencia, España, 2011. Volume 146. pp. 17-20.

34. Lambert, A.; Fantozzi, M.; Shepherd, M. Pressure: Leak flow rates using FAVAD: An improved fast-track practitioner's approach. In Proceedings of the 15th International Conference on Computing and Control for the Water Industry, CCWI 2017, Sheffield, UK, 5-7 September 2017.

35. Sellés, E.G. Caracterización y Mejora de la Eficiencia Energética del Transporte de Agua a Presión; Univ. Politécnica: Valencia, España, $2016 ;$ p. 384.

36. Morales, E.; José, J. Ambiente Título del Trabajo Fin de Máster: Método de los Caudales Minimos Nocturnos: Intensificación: Autor: Máster en Ingeniería Hidráulica y Medio. Master's Thesis, Universitat Politècnica de Valencia, Valencia, España, 2011.

37. Lambert, A. What Do We Know About Pressure: Leakage Relationships in Distribution Systems? In Proceedings of the IWA Specialised Conference: System Approach to Leakage Control and Water Distribution Systems Management, Brno, Czech Republic, 16-18 May 2000; pp. 1-8.

38. Rossman, L.A. The EPANET programmer's toolkit for analysis of water distribution systems. In Proceedings of the WRPMD'99: Preparing for the 21st Century, Tempe, Arizona, 6-9 June 1999; pp. 1-10.

39. Araujo, L.S.; Ramos, H.; Coelho, S.T. Pressure Control for Leakage Minimisation in Water Distribution Systems Management. Water Resour. Manag. 2006, 20, 133-149. [CrossRef]

40. García, I.F.; Novara, D.; Mc Nabola, A. A Model for Selecting the Most Cost-Effective Pressure Control Device for More Sustainable Water Supply Networks. Water 2019, 11, 1297. [CrossRef]

41. Van Zyl, J.E.; Clayton, C.R.I. The effect of pressure on leakage in water distribution systems. Proc. Inst. Civ. Eng. Water Manag. 2007, 160, 109-114. [CrossRef]

42. Ferrante, M.; Brunone, B.; Meniconi, S.; Capponi, C.; Massari, C. The Leak Law: From Local to Global Scale. Procedia Eng. 2014, 70, 651-659. [CrossRef]

43. Cassa, A.; Van Zyl, J. Predicting the Leakage Exponents of Elastically Deforming Cracks in Pipes. Procedia Eng. 2014, 70, 302-310. [CrossRef]

44. Karadirek, I.E.; Kara, S.; Yilmaz, G.; Muhammetoglu, A. Implementation of Hydraulic Modelling for Water-Loss Reduction Through Pressure Management. Water Resour. Manag. 2012, 26, 2555-2568. [CrossRef]

45. Gupta, R.; Abhijith, G.R.; Ormsbee, L. Leakage as Pressure-Driven Demand in Design of Water Distribution Networks. J. Water Resour. Plan. Manag. 2016, 142, 04016005. [CrossRef]

46. Molina, S.X.; Iglesias-Rey, P.L.; Francisco-javier, S. Calibración de modelos de redes de distribución de agua mediante la utilización conjunta de demandas y consumos dependientes de la presión. In Proceedings of the IV Jornadas de Ingeniería del Agua La Precipitación y los Procesos Erosivos, Córdoba, Spain, 21-22 October 2015; Volume 10, pp. 2-3.

47. Marunga, A.; Hoko, Z.; Kaseke, E. Pressure management as a leakage reduction and water demand management tool: The case of the City of Mutare, Zimbabwe. Phys. Chem. Earth Parts A/B/C 2006, 31, 763-770. [CrossRef] 
48. Marzola, I.; Alvisi, S.; Franchini, M. Analysis of MNF and FAVAD Model for Leakage Characterization by Exploiting SmartMetered Data: The Case of the Gorino Ferrarese (FE-Italy) District. Water 2021, 13, 643. [CrossRef]

49. Casanova, A.; Vigueras-Rodriguez, A.; García, J.T.; Castillo, C.L. Evaluación y clasificación de efectos de fugas en la red de abastecimiento de Moratalla (Murcia) para la priorización del mantenimiento de tuberías. In Proceedings of the Jornadas de Ingeniería del Agua, A Coruña, Spain, 24-26 October 2014; pp. 1-13.

50. Muhammetoglu, A.; Karadirek, I.E.; Ozen, O.; Muhammetoglu, H. Full-Scale PAT Application for Energy Production and Pressure Reduction in a Water Distribution Network. J. Water Resour. Plan. Manag. 2017, 143, 04017040. [CrossRef]

51. Kofinas, D.; Ulanczyk, R.; Laspidou, C.S. Simulation of a water distribution network with key performance indicators for spatio-temporal analysis and operation of highly stressedwater infrastructure. Water 2020, 12, 1149. [CrossRef]

52. Abdelmeguid, H.; Ulanicki, B. Pressure and Leakage Management in Water Distribution Systems via Flow Modulation PRVs. In Proceedings of the 12th Annual International Conference on Water Distribution Systems Analysis, Tucson, AZ, USA, 12-15 September 2010; Volume 41203, pp. 1124-1139.

53. Cobacho, R.; Arregui, F.; Soriano, J.; Cabrera, E. Including leakage in network models: An application to calibrate leak valves in EPANET. J. Water Supply: Res. Technol. 2014, 64, 130-138. [CrossRef]

54. Alonso, J.M.; Alvarruiz, F.; Guerrero, D.; Hernández, V.; Ruiz, P.A.; Vidal, A.M.; Martínez, F.; Vercher, J.; Ulanicki, B. Parallel Computing in Water Network Analysis and Leakage Minimization. J. Water Resour. Plan. Manag. 2000, 126, 251-260. [CrossRef]

55. Fontana, N.; Giugni, M.; Marini, G. Experimental assessment of pressure-leakage relationship in a water distribution network Water Sci. Technol. Water Supply 2016, 17, 726-732. [CrossRef]

56. Tucciarelli, D.T.; Criminisi, A. Leak analysis in pipeline systems by means of optimal valve regulation. J. Hydraul. Eng. 1999, 9 , 277-285. [CrossRef]

57. Germanopoulos, G.; Jowitt, P. Leakage reduction by excess pressure minimization in a water supply network. Proc. Inst. Civ. Eng. 1989, 87, 195-214. [CrossRef]

58. Cavazzini, G.; Pavesi, G.; Ardizzon, G. Optimal assets management of a water distribution network for leakage minimization based on an innovative index. Sustain. Cities Soc. 2020, 54, 101890. [CrossRef]

59. Pardo, M.; Riquelme, A. A software for considering leakage in water pressurized networks. Comput. Appl. Eng. Educ. 2019, 27, 708-720. [CrossRef]

60. Mutikanga, H.E.; Sharma, S.K.; Vairavamoorthy, K. Methods and tools for managing losses in water distribution systems. J. Water Resour. Plan. Manag. 2013, 139, 166-174. [CrossRef]

61. Wu, Z.Y.; Sage, P.; Turtle, D. Pressure-Dependent Leak Detection Model and Its Application to a District Water System. J. Water Resour. Plan. Manag. 2010, 136, 116-128. [CrossRef]

62. Di Nardo, A.; Di Natale, M.; Gisonni, C.; Iervolino, M. A genetic algorithm for demand pattern and leakage estimation in a water distribution network. J. Water Supply Res. Technol. 2014, 64, 35-46. [CrossRef]

63. Greyvenstein, B.; van Zyl, J.E. An experimental investigation into the pressure-Leakage relationship of some failed water pipes. J. Water Supply Res. Technol. 2007, 56, 117-124. [CrossRef]

64. Fox, S.; Collins, R.; Boxall, J. Dynamic Leakage: Physical Study of the Leak Behaviour of Longitudinal Slits in MDPE Pipe. Procedia Eng. 2014, 89, 286-289. [CrossRef]

65. Schwaller, J.; Van Zyl, J.E.; Kabaasha, A.M.; Schwaller, J.; Van Zyl, J.E.; Kabaasha, A.M. Characterising the pressure-leakage response of pipe networks using the FAVAD equation. Water Sci. Technol. Water Supply 2015, 15, 1373-1382. [CrossRef]

66. Ferraiuolo, R.; De De Paola, F.; Fiorillo, D.; Caroppi, G.; Pugliese, F. Experimental and Numerical Assessment of Water Leakages in a PVC-A Pipe. Water 2020, 12, 1804. [CrossRef]

67. Thornton, J.; Lambert, A. Progress in practical prediction of pressure: Leakage, pressure: Burst frequency and pressure: Consumption relationships. In Proceedings of the Paper to IWA Special Conference "Leakage 2005", Halifax, NS, Canada, 12-14 September 2005.

68. Giustolisi, O.; Berardi, L.; Laucelli, D.B.; Savic, D.; Walski, T.; Brunone, B. Battle of Background Leakage Assessment for Water Networks (BBLAWN) at WDSA Conference 2014. Procedia Eng. 2014, 89, 4-12. [CrossRef]

69. Braga, A.S.; Fernandes, C.V.S.; Braga, S.M.; Santos, D.C.D. Leakage modeling through empirical equations: An experimental approach. In Proceedings of the 1st International WDSA/CCWI Joint Conference, Kingston, ON, Canada, $23-25$ July 2018.

70. Ríos, J.C.; Santos-Tellez, R.; Rodríguez, M.P.H.; Leyva, E.A.; Martínez, V.N. Methodology for the Identification of Apparent Losses in Water Distribution Networks. Procedia Eng. 2014, 70, 238-247. [CrossRef]

71. Contreras, F.G. Influencia de la presión en las perdidas de agua en sistemas de distribución. In Proceedings of the International Symphony Hydraulic Structures-XXII Congresso Latinoam. Hidraul., Punta del Este, Uruguay, 26-30 November 2006.

72. Rondán, E.; Pino, F.J. Estado del arte de la calibración de modelos hidráulicos. Modelado de fugas con Epanet. Dep. Ing. Energética. 2016, 80, 44-50.

73. De Paola, F.; Cutolo, A.; Giugni, M.; Fraldi, M. Influence of Hole Geometry and Position in Leaking Pipes under Combined Pressure and Bending Regimes. J. Hydraul. Eng. 2019, 145, 04018081. [CrossRef]

74. Girard, M.; Stewart, R.A. Implementation of Pressure and Leakage Management Strategies on the Gold Coast, Australia: Case Study. J. Water Resour. Plan. Manag. 2007, 133, 210-217. [CrossRef]

75. Alkasseh, J.M.A.; Adlan, M.N.; Abustan, I.; Aziz, H.A.; Hanif, A.B.M. Applying Minimum Night Flow to Estimate Water Loss Using Statistical Modeling: A Case Study in Kinta Valley, Malaysia. Water Resour. Manag. 2013, 27, 1439-1455. [CrossRef] 
76. Kabaasha, A.M.; van Zyl, J.E.; Olivier Piller, O. Modelling Pressure: Leakage Response in Water Distribution Systems Considering Leak Area Variation. In Proceedings of the 14th CCWI International Conference, Computing and Control in Water Industry, Amsterdam, The Netherlands, 7-9 November 2016; pp. 1-7.

77. Van Zyl, J.E.; Lambert, A.O.; Collins, R. Realistic Modeling of Leakage and Intrusion Flows through Leak Openings in Pipes. J. Hydraul. Eng. 2017, 143, 04017030. [CrossRef]

78. Rondán, E. Estado del arte de la calibración de modelos hidráulicos. In Modelado de Fugas Con Epanet; Trabajo Fin de Grado Inédito; Universidad de Sevilla: Sevilla, Spain, 2016; p. 80.

79. Puust, R.; Kapelan, Z.; Savic, D.A.; Koppel, T. A review of methods for leakage management in pipe networks. Urban Water J. 2010, 7, 25-45. [CrossRef]

80. González, D.J.V. Diseño de maniobras de gestión de presiones en sectores de distribución de agua y análisis de su impacto. Ph.D. Thesis, Universidad Politécnica de Madrid, Madrid, Spain, 2017.

81. Roma, J.; Pérez, R.; Sanz, G.; Grau, S. Model Calibration and Leakage Assessment Applied to a Real Water Distribution Network. Procedia Eng. 2015, 119, 603-612. [CrossRef]

82. Bonthuys, G.J.; van Dijk, M.; Cavazzini, G. Leveraging water infrastructure asset management for energy recovery and leakage reduction. Sustain. Cities Soc. 2019, 46, 101434. [CrossRef]

83. Bonthuys, G.; Van Dijk, M.; Cavazzini, G. The Optimization of Energy Recovery Device Sizes and Locations in Municipal Water Distribution Systems during Extended-Period Simulation. Water 2020, 12, 2447. [CrossRef]

84. Deyi, M.; Van Zyl, J.; Shepherd, M. Applying the FAVAD Concept and Leakage Number to Real Networks: A Case Study in Kwadabeka, South Africa. Procedia Eng. 2014, 89, 1537-1544. [CrossRef]

85. Moosavian, N.; Jaefarzadeh, M.R. Pressure-Driven Demand and Leakage Simulation for Pipe Networks Using Differential Evolution. World J. Eng. Technol. 2013, 1, 49-58. [CrossRef]

86. Muranho, J.; Ferreira, A.; Sousa, J.; Gomes, A.; Marques, J.A.S. Pressure-dependent Demand and Leakage Modelling with an EPANET Extension-WaterNetGen. Procedia Eng. 2014, 89, 632-639. [CrossRef]

87. Giustolisi, O.; Walski, T.M. Demand Components in Water Distribution Network Analysis. J. Water Resour. Plan. Manag. 2012, 138, 356-367. [CrossRef]

88. Iglesias-Rey, P.L.; Martínez-Solano, F.J.; Meliá, D.M.; Iglesias-Rey, P.L.; Martínez-Solano, F.J.; Meliá, D.M. Combining Engineering Judgment and an Optimization Model to Increase Hydraulic and Energy Efficiency in Water Distribution Networks. J. Water Resour. Plan. Manag. 2016, 142, 1-5. [CrossRef]

89. Zanfei, A.; Menapace, A.; Pisaturo, G.R.; Righetti, M. Calibration of Water Leakages and Valve Setting in a Real Water Supply System. Environ. Sci. Proc. 2020, 2, 41. [CrossRef]

90. Mora-Rodríguez, J.; Delgado-Galván, X.; Ortiz-Medel, J.; Ramos, H.M.; Fuertes-Miquel, V.S.; López-Jiménez, P.A. Pathogen intrusion flows in water distribution systems: According to orifice equations. J. Water Supply Res. Technol. 2015, 64, 857-869. [CrossRef]

91. Adedeji, K.B.; Hamam, Y.; Abu-Mahfouz, A.M. Impact of pressure-driven demand on background leakage estimation inwater supply networks. Water 2019, 11, 1600. [CrossRef]

92. Sophocleous, S.; Savić, D.A.; Kapelan, Z.; Giustolisi, O. A Two-stage Calibration for Detection of Leakage Hotspots in a Real Water Distribution Network. Procedia Eng. 2017, 186, 168-176. [CrossRef]

93. Adachi, S.; Takahashi, S.; Kurisu, H.; Tadokoro, H.; Adachi, S.; Takahashi, S.; Kurisu, H.; Tadokoro, H. Estimating Area Leakage in Water Networks Based on Hydraulic Model and Asset Information. Procedia Eng. 2014, 89, 278-285. [CrossRef]

94. Deb, K.; Pratap, A.; Agarwal, S.; Meyarivan, T. A fast and elitist multiobjective genetic algorithm: NSGA-II. IEEE Trans. Evol. Comput. 2002, 6, 182-197. [CrossRef]

95. Powell, M. The BOBYQA algorithm for bound constrained optimization without derivatives. In NA Report NA2009/06.2009; University of Cambridge: Cambridge, UK, 2009; p. 39.

96. Telci, I.T.; Aral, M.M. Optimal energy recovery fromwater distribution systems using smart operation scheduling. Water 2018, 10, 1464. [CrossRef]

97. Soltanjalili, M.; Bozorg-Haddad, O.; Aghmiuni, S.S.; Mariño, M.A. Water distribution network simulation by optimization approaches. Water Sci. Technol. Water Supply 2013, 13, 1063-1079. [CrossRef]

98. Latchoomun, L.; King, R.A.; Busawon, K. A new approach to model development of water distribution networks with high leakage and burst rates. Procedia Eng. 2015, 119, 690-699. [CrossRef]

99. Quiñones-Grueiro, M.; Milián, M.A.; Rivero, M.S.; Neto, A.J.S.; Llanes-Santiago, O. Robust leak localization in water distribution networks using computational intelligence. Neurocomputing 2021, 438, 195-208. [CrossRef]

100. Giustolisi, O.; Savic, D.; Kapelan, Z. Pressure-Driven Demand and Leakage Simulation for Water Distribution Networks. J. Hydraul. Eng. 2008, 134, 626-635. [CrossRef]

101. Grupo Especialista en Benchmarking y Evaluación del Desempeño de la IWA. Manual de Buenas Prácticas. In Indicadores de Desempeño para Servicios de Abastecimiento de Agua, 3rd ed.; UPV: Valencia, Spain, 2018.

102. Patelis, M.; Kanakoudis, V.; Gonelas, K. Combining pressure management and energy recovery benefits in a water distribution system installing PATs. J. Water Supply Res. Technol. 2017, 66, jws2017018. [CrossRef] 
103. Winarni, W. Infrastructure Leakage Index (ILI) as Water Losses Indicator. Civ. Eng. Dimens. 2009, 11, 126-134.

104. Radivojevic, D.; Milicevic, D.; Blagojevic, B. IWA best practice and performance indicators for water utilities in Serbia: Case study Pirot. Facta Univ. Ser. Arch. Civ. Eng. 2008, 6, 37-50. [CrossRef]

105. Lambert, A. International Report: Water losses management and techniques. Water Sci. Technol. Water Supply 2002, 2, 1-20. [CrossRef]

106. Rosado, L.E.C.; López-Jiménez, P.A.; Sánchez-Romero, F.J.; Fuertes, P.C.; Pérez-Sánchez, M. Applied strategy to characterize the energy improvement using PATs in a water supply system. Water 2020, 12, 1818. [CrossRef]

107. Rosado, L.E.C.; Llácer Iglesias, R.M.; Conejos Fuertes, P.; Pérez-Sánchez, M.; López Jiménez, P.A. Characterization of hydraulic machinery topology for energy recovery in water distribution systems. In Case Study; EN 6th IAHR Europe Congress: Warsaw, Poland, 2021; pp. 800-801.

108. Ristovski, B. Pressure management and active leakage control in particular DMA (Lisiche) in the city of Skopje. Water 2011, 2, 45-49.

109. Cabrera, E.; Cobacho, R.; Soriano, J. Towards an Energy Labelling of Pressurized Water Networks. Procedia Eng. 2014, 70, $209-217$. [CrossRef]

110. Levine, B.; Lucas, J.; Cynar, P.; Hildebrand, T.; Morgan, W. Pressure Management in the Pittsburgh Area: A Working and Economical Solution. In Proceedings of the Paper to IWA Special Conference "Leakage 2005", Halifax, NS, Canada, 12-14 September 2005.

111. Koelbl, J. Sustainable Network Management Practises. In Proceedings of the IWA Efficient 2011 Conference, Jordan, MI, USA, 29 March-2 April 2011.

112. European Commission. EU Reference Document Good Practices on Leakage Management WFD CIS WG PoM; European Commission: Brussels, Belgium, 2015.

113. Giustolisi, O.; Berardi, L.; Laucelli, D.; Savic, D.; Kapelan, Z. Operational and Tactical Management of Water and Energy Resources in Pressurized Systems: Competition at WDSA 2014. J. Water Resour. Plan. Manag. 2016, 142. [CrossRef]

114. Nicolini, M.; Giacomello, C.; Scarsini, M.; Mion, M. Numerical Modeling and Leakage Reduction in the Water Distribution System of Udine. Procedia Eng. 2014, 70, 1241-1250. [CrossRef]

115. Karathanasi, I.; Papageorgakopoulos, C. Development of a Leakage Control System at the Water Supply Network of the City of Patras. Procedia Eng. 2016, 162, 553-558. [CrossRef]

116. Pérez-Sánchez, M.; Sánchez-Romero, F.J.; Ramos, H.M.; López-Jiménez, P.A. Modeling irrigation networks for the quantification of potential energy recovering: A case study. Water 2016, 8, 234. [CrossRef]

117. Al-Washali, T.; Sharma, S.; Lupoja, R.; Al-Nozaily, F.; Haidera, M.; Kennedy, M. Assessment of water losses in distribution networks: Methods, applications, uncertainties, and implications in intermittent supply. Resour. Conserv. Recycl. 2020, $152,104515$. [CrossRef]

118. Negharchi, S.M.; Shafaghat, R. Leakage estimation in water networks based on the BABE and MNF analyses: A case study in Gavankola village, Iran. Water Sci. Technol. Water Supply 2020, 20, 2296-2310. [CrossRef]

119. Giugni, M.; Fontana, N.; Ranucci, A. Optimal Location of PRVs and Turbines in Water Distribution Systems. J. Water Resour. Plan. Manag. 2014, 140, 06014004. [CrossRef]

120. Rossi, M.; Nigro, A.; Pisaturo, G.R.; Renzi, M. Technical and economic analysis of Pumps-as-Turbines (PaTs) used in an Italian Water Distribution Network (WDN) for electrical energy production. Energy Procedia 2019, 158, 117-122. [CrossRef]

121. AAlberizzi, J.C.; Renzi, M.; Nigro, A.; Rossi, M. Study of a Pump-as-Turbine (PaT) speed control for a Water Distribution Network (WDN) in South-Tyrol subjected to high variable water flow rates. Energy Procedia 2018, 148, 226-233. [CrossRef]

122. Fecarotta, O.; McNabola, A. Optimal Location of Pump as Turbines (PATs) in Water Distribution Networks to Recover Energy and Reduce Leakage. Water Resour. Manag. 2017, 31, 5043-5059. [CrossRef]

123. Tricarico, C.; Morley, M.; Gargano, R.; Kapelan, Z.; De Marinis, G.; Savic, D.; Granata, F. Optimal Water Supply System Management by Leakage Reduction and Energy Recovery. Procedia Eng. 2014, 89, 573-580. [CrossRef]

124. Parra, S.; Krause, S. Pressure management by combining pressure reducing valves and pumps as turbines for water loss reduction and energy recovery. Int. J. Sustain. Dev. Plan. 2017, 12, 89-97. [CrossRef]

125. Cimorelli, L.; D'Aniello, A.; Cozzolino, L.; Pianese, D. Leakage reduction in WDNs through optimal setting of PATs with a derivative-free optimizer. J. Hydroinformatics 2020, 22, 713-724. [CrossRef]

126. Nguyen, K.D.; Dai, P.D.; Vu, D.Q.; Cuong, B.M.; Tuyen, V.P.; Li, P. A MINLP Model for Optimal Localization of Pumps as Turbines in Water Distribution Systems Considering Power Generation Constraints. Water 2020, 12, 1979. [CrossRef]

127. Lima, G.M.; Luvizotto, E., Jr.; Brentan, B.M.; Ramos, H.M. Leakage Control and Energy Recovery Using Variable Speed Pumps as Turbines. J. Water Resour. Plan. Manag. 2018, 144, 04017077. [CrossRef]

128. Lima, G.M.; Luvizotto, E.; Brentan, B.M. Selection and location of Pumps as Turbines substituting pressure reducing valves. Renew. Energy 2017, 109, 392-405. [CrossRef] 